\title{
The Interplay of WNT and PPAR $\gamma$ Signaling in Vascular Calcification
}

\author{
Stefan Reinhold $^{1}$, W. Matthijs Blankesteijn ${ }^{1}$ (D) and Sébastien Foulquier ${ }^{1,2, *(D)}$ \\ 1 Department of Pharmacology and Toxicology, Cardiovascular Research Institute (CARIM), Maastricht \\ University, 6200 MD Maastricht, The Netherlands; stefan.reinhold@maastrichtuniversity.nl (S.R.); \\ wm.blankesteijn@maastrichtuniversity.nl (W.M.B.) \\ 2 Department of Neurology, School of Mental Health and Neuroscience, Maastricht University, \\ 6200 MD Maastricht, The Netherlands \\ * Correspondence: s.foulquier@maastrichtuniversity.nl; Tel.: +31-433881409
}

Received: 30 October 2020; Accepted: 8 December 2020; Published: 10 December 2020

\begin{abstract}
Vascular calcification (VC), the ectopic deposition of calcium phosphate crystals in the vessel wall, is one of the primary contributors to cardiovascular death. The pathology of $\mathrm{VC}$ is determined by vascular topography, pre-existing diseases, and our genetic heritage. VC evolves from inflammation, mediated by macrophages, and from the osteochondrogenic transition of vascular smooth muscle cells (VSMC) in the atherosclerotic plaque. This pathologic transition partly resembles endochondral ossification, involving the chronologically ordered activation of the $\beta$-catenin-independent and -dependent Wingless and Int- 1 (WNT) pathways and the termination of peroxisome proliferator-activated receptor $\gamma(\operatorname{PPAR} \gamma)$ signal transduction. Several atherosclerotic plaque studies confirmed the differential activity of PPAR $\gamma$ and the WNT signaling pathways in VC. Notably, the actively regulated $\beta$-catenin-dependent and -independent WNT signals increase the osteochondrogenic transformation of VSMC through the up-regulation of the osteochondrogenic transcription factors SRY-box transcription factor 9 (SOX9) and runt-related transcription factor 2 (RUNX2). In addition, we have reported studies showing that WNT signaling pathways may be antagonized by PPAR $\gamma$ activation via the expression of different families of WNT inhibitors and through its direct interaction with $\beta$-catenin. In this review, we summarize the existing knowledge on WNT and PPAR $\gamma$ signaling and their interplay during the osteochondrogenic differentiation of VSMC in VC. Finally, we discuss knowledge gaps on this interplay and its possible clinical impact.
\end{abstract}

Keywords: vascular calcification; inflammation; vascular smooth muscle cells; macrophages; atherosclerosis; cardiovascular disease; PPAR $\gamma$; WNT; $\beta$-catenin

\section{Introduction}

Cardiovascular disease (CVD) affects more than 420 million people worldwide, causing 18 million deaths annually. A recently published study postulated an increase to 23 million deaths by 2030, which will increase the global economic burden of CVD to USD 1.044 billion. About 70\% of these deaths are due to coronary heart disease (CHD) or ischemic strokes, outcomes that are mainly caused by the vascular disease atherosclerosis [1-3].

The atherosclerotic plaque manifests as single or multiple pathological deposits in the aorta's vascular wall or in its branching arteries. These deposits mainly consist of living and dead cells, as well as lipids that accumulate in the vessel wall. Ultimately, the plaque may narrow the affected artery, which induces ischemia in the supplied organs. This narrowing results in CVDs such as CHD, peripheral artery disease, as well as acute vascular events like myocardial infarction and stroke. Notably, patients with atherosclerosis frequently suffer from vascular calcifications (VC), an ectopic deposition of calcium phosphate crystals in the atherosclerotic plaque [2]. 
Atherosclerosis of the coronary arteries often leads to acute and chronic complications associated with coronary artery calcification (CAC). The prevalence of CAC alternates between 50 and $70 \%$ and depends on ethnicity, which was confirmed by the Multi-Ethnic Study of Atherosclerosis that compared the prevalence of CAC in the Black, White, Chinese and Hispanic population, finding the highest risk for CAC in the White population [4]. Moreover, elevated CAC increases the risk of coronary events such as myocardial infarction by 10 -fold, whereas overall VC increases mortality by up to 4 -fold $[5,6]$. Consequently, understanding risk factors for VC, such as oxidative stress, inflammation and abnormal mineral metabolism (hyperphosphatemia, hypercalcemia), is essential to develop new treatments or even to prevent VC.

Atherosclerotic risk factors include metabolic diseases like type 1 and type 2 diabetes (T1D/T2D), chronic kidney disease (CKD) as well as lifestyle factors like Western diet, smoking and obesity [2]. The steady increase of metabolic diseases in emerging countries, due to the raising life expectancy combined with the introduction of the Western diet, is alarming. Many scientists expect this trend to continue, generating higher mortality rates, posing an enormous burden for global healthcare systems [1,7]. Lately, a study of the indigenous Tsimane population, leading a pre-industrial lifestyle, found that $85 \%$ of the population was free from CAC, highlighting the effect of diet and physical activity on VC [8]. In contrast, athletes with a high physical activity display a higher prevalence of CAC than sedentary people, while still having a lower incidence of CVD and longer life expectancy [9]. These varying effects of CAC in different population groups indicate that a change in diet and physical exercise may positively change the impact of VC. Consequently, it appears necessary to examine calcification morphology (see Section 1.1 of this review) to explain the differential effects of VC for vascular events.

This review aims to present a brief overview of VC pathology and the participating cells. At first, we will explain the similarities between VC and endochondral ossification, as well as the contributing role of inflammation. Subsequently, the respective roles of Wingless/Int-1 (WNT)- and Peroxisome proliferator-activated receptor $\gamma(\operatorname{PPAR} \gamma)$ signaling in atherosclerosis and VC will be explained before discussing existing knowledge about their interplay as well as its relevance for VC.

\subsection{The Pathology of Vascular Calcification}

Historically, VC was assumed to be a passive consequence of vascular injury. However, research demonstrated that VC is an actively regulated process that involves inflammation, oxidative stress and mechanisms similar to endochondral ossification [10,11]. The loss of physiological calcification inhibitors such as Fetuin-A, Osteoprotegerin (OPG) or matrix GLA protein significantly contributes to VC. Nonetheless, a detailed discussion of this topic is beyond the scope of this review $[12,13]$.

The presence and morphology of VC is a significant feature of an atherosclerotic lesion and seems essential to identify unstable plaques, which could help to predict acute vascular events [14]. Calcifications consist of calcium phosphate crystal deposits that can be distinguished by their location, in arterial intimal (AIC) and arterial medial calcification (AMC) as well as by their size for macro$(>15 \mu \mathrm{m})$ and microcalcifications $(0.5-15 \mu \mathrm{m})$ [10]. Additionally, to its occurrence in atherosclerosis, AMC manifests as Monckeberg's arteriosclerosis. AIC, on the other hand, only occurs in atherosclerotic plaques and is strongly associated with inflammation [10]. Both conditions seem to be mainly driven by the osteochondrogenic transition of vascular cells.

Microcalcifications, presumably, can coalesce to larger macrocalcifications, and more extensive calcifications can increase vascular stiffness, an important and independent predictor of CVDs [15, 16]. In contrast, there is evidence that macrocalcifications with a sheet-like morphology stabilize the atherosclerotic plaque. Consequently, macrocalcifications could be predominantly beneficial by preventing plaque ruptures and, thus, vascular events $[10,14]$.

The Tampere vascular study found that the gene expression in atherosclerotic plaques differs by up to $50 \%$ between arterial beds, including genes responsible for inflammation, extracellular matrix modulation and lipid uptake [17]. This genetic difference is the first stepstone to explain why 
$80 \%$ of the plaques found in the peripheral arteries of the lower limbs show extensive, sheet-like calcifications, whereas microcalcifications occur in $43 \%$ and $47 \%$ of the plaques from the coronary arteries and the abdominal aorta, respectively [18]. Many studies demonstrated that microcalcifications can enhance the mechanical and hemodynamic stress on the fibrous cap of the plaque and, thus, increasing the chance of plaque ruptures $[10,14]$. This suggests that plaque ruptures occur more often in the thoracic aorta and the coronary arteries than in the lower-limb arteries. Besides the vascular topography, the embryonic origin of the contributing cells, and the etiology of the preexisting disease contribute to the heterogeneous calcifying properties of the atherosclerotic lesion [18-20].

Various, commonly used drugs and their effects on VC were studied in the last decades, including Statins, PCSK-9 inhibitors, calcium channel blockers, bisphosphonates and Renin-Angiotensin System (RAS) inhibitors [21,22]. Statins and the novel PCSK9-Inhibitors are used to lower the lipid levels in patients, and because of their anti-inflammatory effects, they were suggested to be beneficial for treating VC. Clinical studies for both groups showed conflicting results, mostly demonstrating a plaque stabilizing and pro-calcifying effect [21-23]. Similar, discouraging results regarding VC were found for antihypertensive RAS Inhibitors, bisphosphonate, and for calcium channel blockers [22]. Despite the limited number of studies, a promising option for the treatment of VC could be Vitamin K, essential for the carboxylation of the calcification inhibitor matrix GLA protein, which decreases during the progression of CKD [12,22]. Taken together, there are many different approaches and several new drugs are studied to tackle VC. However, there is no evidence that the mentioned drugs directly affect the detrimental, osteochondrogenic differentiation of VSMC.

While treating VC seems complex, its proper diagnosis is also puzzling. Visualizing VCs by computer tomography is common practice. However, due to the low resolution of this method, it only allows the detection of large calcifications. The visualization of microcalcifications-the culprit behind plaque ruptures and acute vascular events-remains challenging, making it difficult to classify atherosclerotic calcifications. Consequently, the correct diagnosis of disease progression in the clinical setting appears difficult, limiting the application of drugs to prevent or treat VC. Currently, only ${ }^{18} \mathrm{~F}$-sodium fluoride-positron emission tomography can detect microcalcifications with high sensitivity, a method that received more attention for the diagnosis of VC over the past years [14].

Overall, VC is not solely responsible for vascular events since macro-calcifications may offer protection at the cost of vascular stiffness. In addition, clinicians lack proper diagnostic tools and drugs to identify and treat VC. This underlines the urgency to investigate further plaque heterogeneity and the cellular fate of the contributing cells.

\subsection{The Role of Vascular Smooth Muscle Cells and Macrophages in Vascular Calcification}

Early atherosclerotic disease results from a lesion known as a fatty streak, a visible collection of lipid-laden macrophages, called foam cells, in the vessel wall. This lesion develops to pathological intimal thickening, characterized by the migration of VSMCs from the vessel's medial layer to the intima. Subsequently, a fibroatheroma arises, defined by a fibrous cap and a lipid-rich, necrotic core (Figure 1). 


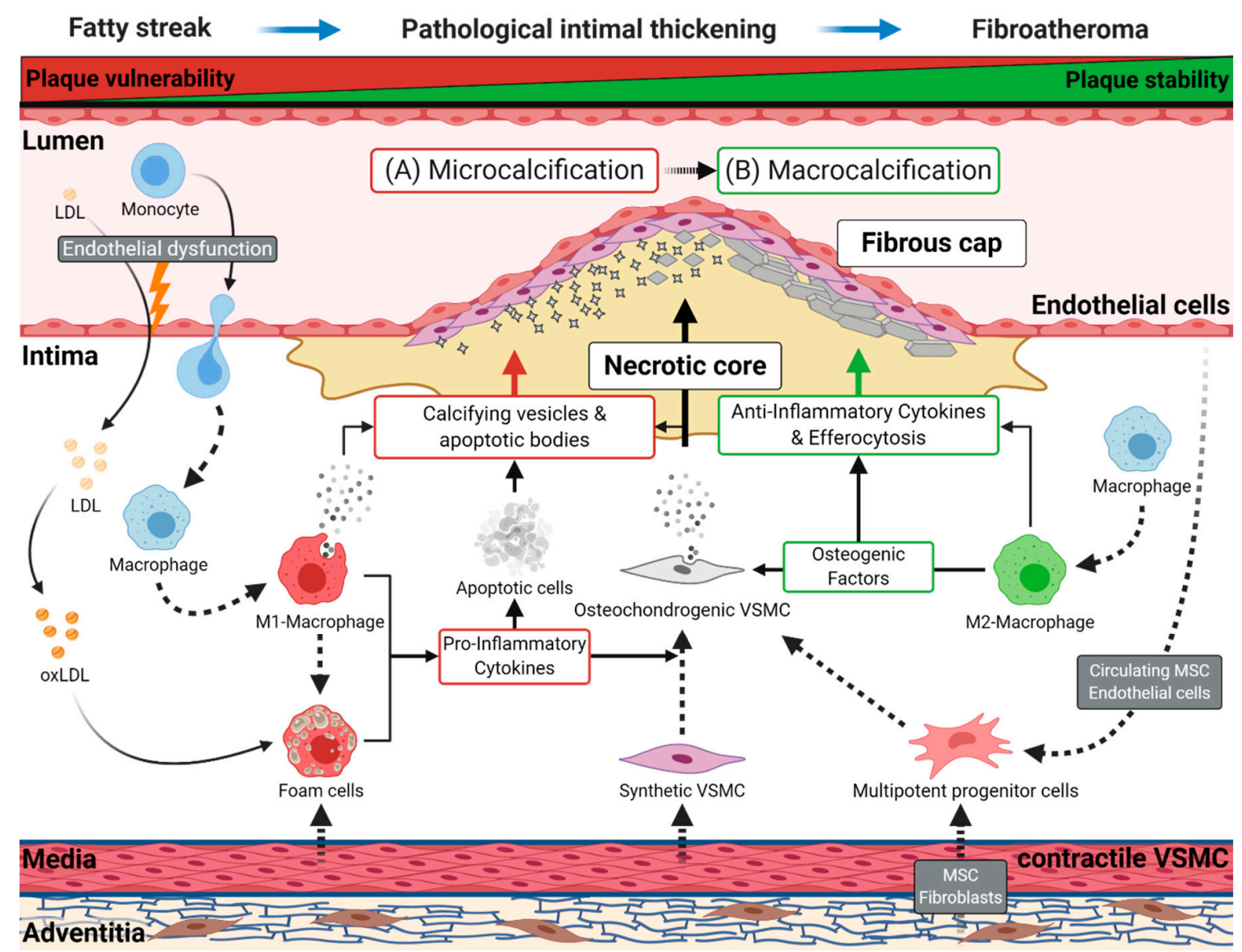

Figure 1. Schematic representation of atherogenesis and intimal vascular calcification. Endothelial dysfunction promotes retention of low-density lipoprotein (LDL) in the intima and the diapedesis of monocytes. Subsequently, retained LDL transforms to oxidized LDL (oxLDL), and monocytes migrating to the intima differentiate into macrophages. Later, these cells can switch to pro-inflammatory M1 or anti-inflammatory M2 macrophages. Resting macrophages and M1 macrophages can absorb oxLDL, which converts them into foam cells. These cells start forming the lipid-rich, necrotic core of the atherosclerotic plaque, which first occurs as a fatty streak in the vessel wall, the earliest sign of atherogenesis. During disease progression, vascular smooth muscle cells (VSMC) acquire a synthetic phenotype and migrate into the plaque contributing to foam cell formation and the stabilization of the fibrous cap. Foam cells and M1 macrophages induce a chronic, pro-inflammatory environment through the secretion of numerous cytokines. The resulting chronical inflammation and the subsequent consumption of oxLDL leads to the apoptosis of these lipid-laden cells and others cell types, causing the shedding of apoptotic bodies into the atherosclerotic plaque. (A) During early atherogenesis (e.g., pathological intimal thickening, fibroatheromas), apoptotic bodies originating from apoptotic cells, and calcifying vesicles, secreted by M1 macrophages, serve as the first nidus for microcalcifications, favoring unstable plaque formation. Subsequently, contractile VSMCs obtain a proliferative synthetic phenotype, leading to their migration into the intima to build the fibrous cap. The continuous inflammatory environment, induced by M1 macrophages and foam cells, initiates the osteochondrogenic transition of synthetic VSMC, contributing to micro- and macrocalcification. (B) In the further course of atherogenesis, M2 macrophages promote the progression of calcification through extracellular matrix deposition and by secreting various osteogenic factors, which may favor the development of sheet-like calcifications. Subsequently, M2 macrophages resolve inflammation by secreting anti-inflammatory cytokines and by removing apoptotic cells through efferocytosis. These mechanisms lead to regression and stabilization of the atherosclerotic plaque. Other vascular cells, originating from the adventitia (fibroblasts, pericytes, mesenchymal stem cells) or the endothelial cell layer, are potential sources for multipotent progenitor cells. The progenitor cells may contribute to the osteochondrogenic cell population in the plaque. 


\subsubsection{The Osteochondrogenic Transition of VSMC during Vascular Calcification}

During pathological intimal thickening, VSMCs change from a contractile to a proliferative synthetic phenotype. This phenotype transition is characterized by the loss of contractile markers like calponin-1, actin alpha 2 (ACTA2, also known as $\alpha$-smooth muscle actin), and by adopting a mesenchymal stem cell (MSC)-like plasticity [24,25]. The MSC-like plasticity indicates two key points: First, it seems to enable synthetic VSMC to acquire an osteochondrogenic phenotype to further accelerate plaque mineralization $[25,26]$. Second, this may indicate a signaling pathway activity comparable to MSC, in which osteogenesis and adipogenesis are balanced by competing transcription factors [27]. Endothelial cells and fibroblasts also can obtain this MSC-like plasticity, making them notable contributors to the osteochondrogenic cell population in the atherosclerotic lesion [26]. Furthermore, MSCs can migrate from the bloodstream into the atherosclerotic plaque, although their role for VC is not clear [28]. There is evidence that MSCs undergo an osteogenic transition when they are in contact with osteochondrogenic VSMC. This osteogenic transition might explain why advanced osteoid structures occur in advanced atherosclerotic plaques [29,30]. It further underlines the importance of the microenvironment for the fate of MSC, concluding that the pathological environment in atherosclerosis may drive MSC to become calcifying cells.

The main osteochondrogenic transcriptions factors SRY-box transcription factor 9 (SOX9) and runt-related transcription factor 2 (RUNX2, also known as CBFA1) are found in atherosclerotic plaques, being mainly expressed in osteochondrogenic VSMC [31-34]. These factors are essential during endochondral ossification, paving the way for MSC to differentiate to chondrocytes and, finally, to osteoblasts [11]. Similar to osteoblasts and chondrocytes, osteochondrogenic VSMC secrete extracellular vesicles loaded with calcium phosphate crystals and osteogenic factors like alkaline phosphatase (ALP) $[35,36]$. These vesicles may calcify on their own and further accelerate mineralization through the loaded osteogenic factors, making them an essential contributor to VC. In contrast, comparison of the transcriptome of osteochondrogenic VSMC- and MSC-derived osteoblasts revealed the heterogeneity of these cell types but also significant similarities in gene clusters responsible for the regulation of mineralization and the extracellular matrix (ECM) [37]. Compared to osteoblasts, osteochondrogenic VSMCs display enhanced apoptosis, reduced expression of osteogenic markers such as RUNX2, and decreased (ALP activity. The latter inhibits the endogenous calcification inhibitor pyrophosphate, hence, pathologically high ALP levels, as found in T2D or CKD, enable the deposition of hydroxyapatite crystals in the vessel wall [38]. Furthermore, calcifications close to osteochondrogenic VSMC in atherosclerotic plaques usually occur in small, discrete regions, while osteoblasts in bone tissue form large nodules associated with collagen deposition [39]. The different mineralization patterns of these two cell types may indicate that VSMCs do not undergo a complete transition to an osteoblast-like cell due to the atherosclerotic microenvironment. Instead, the trans-differentiation of VSMC may be halted during early atherogenesis, resembling a phenotype between chondrocyte and osteoblast. Consequently, VSMCs are essential for the induction of micro- and macrocalcifications in the vessel wall. However, these mechanisms are strongly influenced by the macrophage population's inflammatory conditions in the lesion.

\subsubsection{The Role of Macrophages and Inflammation in Vascular Calcification}

Macrophages act as an inflammatory modulator in atherosclerosis and are derived from monocytes migrating to the atherosclerotic plaque. Classically, the macrophage phenotypes were divided into M1 and M2 macrophages. Although this is a significant simplification since multiple macrophage subtypes are known, we will only refer to M1 and M2 macrophages in the following chapters, to ease the mechanistic understanding of this review [40].

As presented in Figure 1, inflammation is mainly mediated by M1 macrophages through the secretion of pro-inflammatory cytokines such as tumor necrosis factor alpha (TNF $\alpha$ ), interleukin (IL) $1 \beta$ or IL6 during early atherogenesis. The involved cytokines also start the osteochondrogenic program in VSMC, but persistent inflammation hinders further osteogenic maturation of the cells-a mechanism 
also observed during bone healing and inflammatory bone diseases [41,42]. The chronic inflammation keeps VSMC in an early osteochondrogenic state, while also increasing apoptosis. Both mechanisms trigger microcalcifications that, in turn, may further accelerate inflammation through the activation of macrophages [43]. On the other hand, M2 macrophages coordinate plaque regression by decreasing inflammation and secretion of osteogenic factors, leading to the maturation of osteochondrogenic VSMC and stabilizing the atherosclerotic plaque [41]. The M2 phenotype is present during early atherogenesis but may directly polarize to the pro-inflammatory M1 phenotype due to the chronically inflamed plaque microenvironment. Therefore, it was hypothesized that influencing the microenvironment may promote a switch back to M2 macrophages, which would support efferocytosis, ultimately leading to the clearance of dead cells and plaque regression [44]. As mentioned, M2 macrophages also have pro-osteogenic effects on VSMC, making the effect of this transition in the context of VC debatable [41]. Macrophages can also affect VC through the secretion of vesicles that contain Annexin 5 and S100A9, proteins that may aggregate with phosphatidylserine on the vesicle membrane, serving as a potential nucleation site for crystallization and, thus, may increase microcalcifications independent of osteochondrogenic differentiation of VSMC $[45,46]$.

Various biochemical signaling networks, such as the bone morphogenetic protein $(\mathrm{BMP}) /$ transforming growth factor-beta (TGF $\beta$ ) signaling and the receptor activator of nuclear factor- $\mathrm{kB}$ ligand (RANKL)/OPG/TNF-related apoptosis-inducing ligand (TRAIL) pathway are involved in the development of VC. Physiologically, the RANKL-OPG-TRIAL axis is essential for limiting bone loss due to osteoclasts, but dysregulation of this axis appears to play a detrimental role in the progression of VC [47]. Similar accounts for the BMP/TGF $\beta$ family, which regulates SOX9 and RUNX2 during endochondral ossification. The dysregulation of this pathway in VSMC is well known to play a role in their osteochondrogenic differentiation, and BMP-2 was found to induce WNT signaling activity. Notably, the WNT signaling pathway is essential for endochondral ossification by controlling the osteochondrogenic transition of MSC - a mechanism similar to the osteochondrogenic transition of VSMC during VC [31-34]. In MSC, the PPAR $\gamma$ signaling pathway inhibits endochondral ossification by interfering with the WNT signaling pathways, and comparable crosstalk in VSMC seems plausible [48]. The activation of PPAR $\gamma$ signaling demonstrated immunomodulatory properties in macrophages; thus, deciphering the interplay between PPAR $\gamma$ and WNT signaling in atherosclerosis may improve our understanding of VC [44].

\section{The WNT Signaling Pathways}

Nusse and Varmus described first parts of the WNT signaling network in 1982. Almost 40 years have passed, and WNT signaling has been shown to determine the fate of stem cells, making it essential for embryonal development and tissue homeostasis [49]. This signaling network is divided into three pathways; WNT/ $\beta$-catenin-mediated signaling-commonly referred to as the canonical pathway, and the two $\beta$-catenin independent pathways, namely the planar cell polarity and $\mathrm{WNT} / \mathrm{Ca}^{2+}$-mediated signaling, also known as the non-canonical pathways. The WNT ligand family consists of 19 lipid-modified, secreted glycoproteins, able to induce autocrine and paracrine signaling. In the cell, WNT/ $\beta$-catenin signal transduction follows binding of a WNT ligand to a receptor of the frizzled (FZD) family and the lipoprotein receptor-related protein five or six (LRP5/6). Consequently, $\beta$-catenin accumulates in the nucleus and binds to transcription factors of the T-cell factor/lymphoid enhancer-binding (TCF/LEF) family, directing the transcription of the target gene [50]. Without WNT activation the intracellular $\beta$-catenin binds to the $\beta$-catenin destruction complex, consisting of glycogen synthase kinase 3- $\beta$ (GSK3 $\beta$ ), Axin, adenomatous polyposis coli (APC), and casein kinase-1 (CK1), and becomes phosphorylated. The ubiquitin-proteasome system then degrades phosphorylated $\beta$-catenin, hindering signal transduction. The $\beta$-catenin independent pathways, the planar cell polarity and the WNT/Ca ${ }^{2+}$ pathway, are transducing their signals in a different receptor context, involving FZD receptors and different co-receptors such as receptor tyrosine kinase-like orphan receptors one or two (ROR1/2) and related to receptor tyrosine kinase, while inhibiting WNT/ $\beta$-catenin signaling. In 
addition, several regulatory molecules, namely the LRP5/6 inhibitors sclerostin, the dickkopf (DKK) protein family as well as the WNT ligand scavenging secreted frizzled receptor protein (sFRP) family, are regulating these molecular pathways. Aberrant WNT signal transduction plays an essential role in CVD, making this pathway a versatile subject to study in pathologies like VC as reviewed by our group [51].

\subsection{The Role of WNT Signaling in the Initiation of Bone Development}

Bone tissue develops either by intramembranous or endochondral ossification. During intramembranous ossification, MSCs directly differentiate towards osteoblasts to form the calvaria and clavicle bones. In contrast, endochondral ossification forms the remaining parts of the skeleton. In this process, chondrocytes develop from MSC and differentiate into osteoblasts. Numerous signaling pathways, including Hedgehog, Notch, BMP, as well as many others, control this developmental mechanism [27]. Especially, the WNT pathways play an inherent function in this developmental process by modulating the osteochondrogenic determinants SOX9 and RUNX2 in a stage-dependent manner [48].

The WNT signaling ligand WNT5a can start the chondrogenic program by inducing signal transmission through the WNT/Ca ${ }^{2+}$ pathway. This signal is mediated by $\mathrm{Ca}^{2+}$, which activates calcineurin (CaN) and, subsequently, the $\mathrm{Ca}^{2+} /$ calmodulin-dependent protein kinase II (CaMKII). Afterwards, CaMKII dephosphorylates the nuclear factor of activated T-cells (NF-AT). This post-translational modification leads to the translocation of NF-AT to the cell nucleus, where it drives the transcription of the chondrogenic determinant SOX9 [52]. Consequently, this enables the transcription of SOX5 and SOX6, which further stimulates SOX9 transcription in a positive feedback loop, initiating chondrogenesis by modulating the gene expression of ECM proteins like collagen type II alpha (COL2A1) and aggrecan (ACAN) [53,54]. Concurrently, SOX9 facilitates the phosphorylation of $\beta$-catenin, leading to its degradation and hindering transcription of $W N T / \beta$-catenin target genes such as RUNX2. Accordingly, the degradation of $\beta$-catenin contributes to the disruption of chondrocyte maturation while also inhibiting the initiation of osteogenesis as a consequence $[54,55]$. On the other hand, SOX9 deficiency impairs limb development in mice by preventing RUNX2 expression in the skeleton, and the SOX-trio consisting of SOX5, 6 and 9, is essential to induce RUNX2 expression [56,57]. Therefore, functional SOX9 signaling is also vital to set the course for chondrocyte maturation and osteogenesis.

During chondrocyte maturation, the stabilization of $\beta$-catenin plays an indispensable role. The stabilized $\beta$-catenin, together with TCF1, can bind to the promoter region of the osteogenic determinant RUNX2 to induce its transcription [58]. This mechanism initiates osteoblast differentiation by inducing protein expression essential for further osteoblast development, such as ALP, Osteocalcin $(\mathrm{OCN})$, Osteopontin (OPN) and Osterix (OSX) [11,59].

The WNT signaling pathways are not only involved in endochondral ossification, but they also received considerable attention in connection with bone and cardiovascular diseases [51]. For instance, mutations of LRP5 can pathologically increase bone mass by inhibiting the binding of WNT inhibitors such as sclerostin or DKK1, whereas mutations of LRP6 are associated with CHD [60,61]. Consequently, it seems plausible to expect a role for the WNT signaling pathways in atherosclerosis and VC.

\subsection{WNT Signaling in Vascular Calcification}

As mentioned in Section 1.2, calcified atherosclerotic plaques, as well as synthetic and osteochondrogenic VSMC, display expression of SOX9 and RUNX2. Both transcription factors are regulated through WNT signaling and as a consequence, numerous downstream genes-important for ECM remodeling and calcification-such as COL2A1, ACAN, OCN, and ALP are found in calcified lesions [31-34]. 


\subsubsection{Non- $\beta$-Catenin-Mediated WNT Signaling and SOX9 in Vascular Calcification}

The expression of WNT5a, an activator of the chondrogenic determinant SOX9, is found commonly in calcified atherosclerotic plaques [62-64]. In the radial arteries of patients with end-stage renal disease, this expression was shown to correlate with VC [65]. Similarly, the WNT5a concentration of serum was found to correlate with VC and CHD in obese patients with atherosclerosis [66]. This proposes that WNT5a contributes to VC, in turn, this also raises the question which cells are responsible for the secretion of WNT5a.

Recently published data revealed osteochondrogenic VSMC as a potential source for WNT5a, which seems plausible since WNT5a often is detected near calcifications [67]. However, the increase of WNT5a expression in VSMC was found in vitro and after the transition to the osteochondrogenic phenotype. Therefore, the initial pool of WNT5a, which potentially initiates the osteochondrogenic transition of VSMC, has to originate from elsewhere.

Notably, WNT5a expression often locates near macrophage-rich regions, proposing macrophages as a potential source for WNT5a [62-64]. In macrophages, inflammatory factors like TNF $\alpha$, IL6, or oxidized low-density lipoprotein (oxLDL) can induce WNT5a expression. Moreover, a positive feedback loop between IL6 and WNT5a exists in other diseases, which may indicate a similar mechanism in atherosclerosis $[63,68]$. The inflammatory factors present in the atherosclerotic plaque may drive macrophages to secrete WNT5a to promote the transition of VSMC to an osteochondrogenic phenotype. Equally important, the perivascular and the thoracic adipose tissue were described as potential sources for WNT5a, increasing the contributing cell pool further [66].

As mentioned in Section 1.2, MSCs may have a role in VC and, indeed, in vitro experiments showed that WNT5a/ROR2 signaling induces the osteochondrogenic transition of MSC when they are in direct contact with calcified VSMC, potentially accelerating VC [69]. However, MSCs that were indirectly co-cultivated with healthy VSMC during calcification, actually attenuated the osteochondrogenic transition of VSMC by interfering with WNT5a, ROR2 and $\beta$-catenin protein expression, indicating a protective mechanism under specific circumstances [70]. It is debatable, however, if there are comparable mechanisms in vivo, since no data are available.

\subsection{2. $\beta$-Catenin-Mediated WNT Signaling and RUNX2 in Vascular Calcification}

A study on VC in rats with end-stage CKD did not show a significant increase in WNT5a but of the canonical WNT/ $\beta$-catenin ligand WNT3a. Moreover, a correlation was found between the expression of $\beta$-catenin — the central signaling transducer of the WNT/ $\beta$-catenin pathway-and VC [71]. These results align with numerous other studies that found an increased $\beta$-catenin activity or expression in osteochondrogenic VSMC and calcified atherosclerotic plaques $[65,71-73]$. The differential expression and activity of WNT5a and $\beta$-catenin indicate a switch from the non- $\beta$-catenin-mediated WNT signaling to the WNT/ $\beta$-catenin pathway as occurring during endochondral ossification. The switch between these signaling pathways may demonstrate the continuous osteochondrogenic transition of VSMC and, thus, indicates the progression of atherosclerotic calcifications.

Calcified plaques display a high expression of RUNX2, which is essential for the full osteochondrogenic transition of VSMC [32,33]. Correspondingly, VSMC treated with high phosphate to simulate conditions observed in CKD, differentiate into osteochondrogenic VSMC while displaying high levels of RUNX2 [33,72-74]. Considering that RUNX2 expression relies on active WNT/ $\beta$-catenin signaling in endochondral ossification, it seems plausible to expect a similar signal transduction in VC. For instance, Rats with CKD—a disease with a high prevalence for VC—display a positive correlation between active $\beta$-catenin and RUNX2 expression in the vasculature [71]. In VSMC, WNT/ $\beta$-catenin ligands such as WNT3a, WNT7b, and WNT8b induce RUNX2 expression. Moreover, expression of transcriptional RUNX2 targets such as OCN, OSX, and ALP, is common in osteochondrogenic VSMC and calcified plaques $[33,58,72-74]$. The VSMC specific deletion of RUNX2 in LDLR ${ }^{-1}$ mice abolishes the occurrence of AMC and AIC and the expression of OCN and ALP [33,75]. 
In essence, the aberrant WNT5a/SOX9 signal transmission in atherosclerosis seems to set the stage to initiate atherosclerotic calcification (Figure 2A). Later on, a switch to WNT/ $\beta$-catenin signaling occurs, which is required for RUNX2 expression, to ultimately drive the osteochondrogenic transition of VSMC in VC (Figure 2B).


Figure 2. Schematic representation of the Wingless and Int-1 (WNT) signaling pathways and their role during the osteochondrogenic transition of synthetic vascular smooth muscle cells (VSMC). (A) Chronic inflammation stands at the beginning of early atherogenesis and initiates the $\beta$-catenin-independent WNT signal transmission, which sparks the osteochondrogenic differentiation of VSMC. Transforming growth factor $\beta$ (TGF $\beta$ ) binds to the low-density lipoprotein receptor 1 (LRP1), leading to the expression of WNT5a through an unknown mechanism in VSMC. WNT5a, mainly originates from surrounding macrophages and binds to frizzled receptors (FZD) and receptor tyrosine kinase-like orphan receptors 1 or $2(\mathrm{ROR} 1 / 2)$. This activation induces the $\mathrm{WNT} / \mathrm{Ca}^{2+}$ pathway involving $\mathrm{Ca}^{2+} /$ calmodulin-dependent protein kinase II (CaMKII) and Calcineurin (CaN). Subsequently, CaN dephosphorylates the nuclear factor of activated T-cells (NF-AT), leading to the translocation of NF-AT to the nucleus where it initiates the transcription of the chondrogenic determinant SRY-box transcription factor 9 (SOX9), inducing the expression of extracellular matrix proteins like Aggrecan (ACAN), Collagen type II alpha (COL2A1), SOX5, and SOX6. (B) In late atherogenesis, conditions like hyperphosphatemia increase $\mathrm{WNT} / \beta$-catenin signaling activity by inducing the expression of $\mathrm{WNT} / \beta$-catenin ligands such as WNT3a. Binding of WNT3a to FZDs, co-activates lipoprotein receptor-related protein 5 or 6 (LRP5/6) inducing the recruitment of dishelved (DVL) protein to the receptor complex. Subsequently, DVL binds the $\beta$-catenin destruction complex, containing glycogen synthase kinase $3 \beta$ (GSK3 $\beta$ ), axin, adenomatous polyposis coli (APC) and casein kinase-1 (CK-1). This leads to an accumulation of $\beta$-catenin in the cytoplasm, followed by its translocation to the nucleus where it forms a complex with T-cell factor/lymphoid enhancer factor (TCF/LEF) to induce transcription of the osteogenic determinant runt-related transcription factor 2 (RUNX2) and the PPAR $\gamma$ inhibitor Cyclin D1. RUNX2 controls the transcription of osteogenic factors such as Osteocalcin (OCN), Osterix (OSX), Osteopontin (OPN), matrix metalloprotease 13 (MMP13), and alkaline phosphatase (ALP).

\subsection{The Role of WNT Inhibitors}

The role of the DKK protein and secreted frizzled-related protein (sFRP) family in bone development, atherosclerosis and VC has been discussed in detail recently [76-78]. For this reason, we will further address the relationship between WNT inhibitors and VC in the following chapter. 


\subsubsection{The Dickkopf Protein Family}

DKK1 was the first discovered DKK protein and, like DKK2 and DKK4, is known to antagonize WNT/ $\beta$-catenin signaling by acting together with Kremen (Kre) co-receptors to direct the endocytosis of LRP5/6, inhibiting further signal transduction [51]. Several studies correlated elevated DKK1 serum or plasma concentration, with the prevalence of CVD and particularly vascular events, indicating a specific role in atherosclerosis [79-82].

In the vasculature, platelets and endothelial cells are sources of DKK1 $[79,80]$. Pro-atherosclerotic factors like shear stress or oxLDL are able to induce DKK1 expression in endothelial cells. Additionally, platelet activation through thrombin increases DKK1 secretion $[79,83,84]$. This excessive DKK1 secretion may contribute to inflammation, monocyte adhesion, and apoptosis of endothelial cells, ultimately, promoting endothelial dysfunction-the initiating step to atherosclerosis. Furthermore, DKK1 regulates the de-differentiation of endothelial cells to MSC, a mechanism commonly found in atherosclerosis $[85,86]$. The endothelial-to-mesenchyme transition could contribute to the amount of MSCs in the atherosclerotic plaque. In the presence of osteochondrogenic VSMC, these MSC tend to undergo an osteogenic transition, which likely promotes VC [69]. In contrast, an inverse correlation between low serum levels of DKK1 and VC was found in several studies, while in vitro DKK1 also attenuates calcium deposition and expression of RUNX2 in osteochondrogenic VSMC [72,74,87,88]. Consequently, DKK1 may limit the osteochondrogenic transition of VSMC, which could prolong the occurrence of instable atherosclerotic plaques by hindering the build-up of stabilizing, sheet-like calcifications during late atherogenesis. This and the negative effects on endothelial function might explain the strong association between DKK1 and CVD.

The knowledge about other DKK proteins and their function in atherosclerosis and VC remains limited. In osteoblasts, DKK2 may activate the $W N T / \beta$-catenin cascade and modulate osteogenic signaling, whereas DKK4 seems to suppress osteogenic lineage determination in bone marrow-derived MSC [89-92]. Henceforth, it is questionable if both factors also affect the synthetic VSMC—osteochondrogenic transition.

In contrast to the other DKK proteins, DKK3 performs its action through binding of Krm1 or Krm2 and not by binding LRP6, however, the signaling pathways influenced by DKK3 are complex and not fully understood [76,93]. In atherosclerosis, DKK3 may enhance plaque stability by inducing the transition of fibroblast to VSMC and increasing ECM deposition, both essential factors for VC [94]. This may suggest a role for DKK3 in promoting VC, although this hypothesis remains to be studied.

\subsubsection{The Secreted Frizzled-Related Protein Family}

The sFRP family is well-known to antagonize both $\beta$-catenin dependent and independent WNT signaling by scavenging WNT ligands and by interacting with FZD receptors to inhibit the binding of other ligands. Nevertheless, the sFRP protein family may also act as WNT ligand transporters, giving them a putative function in WNT signal transduction. Despite the broad expression of these proteins in aortic VSMC, their role in controlling WNT signaling during VC appears unclear [95].

In fibroblasts, sFRP1 controls chondrogenic fate by attenuating SOX9, RUNX2 and COL2A1, which was associated with decreased WNT/ $\beta$-catenin signaling [96]. Mice without sFRP1 expression exhibit an increased RUNX2 and OCN expression as well as increased bone mass, indicating that sFRP1 loss leads to a faster chondrocyte maturation and, consequently, earlier induction of osteogenesis [58]. Similarly, sFRP2 reduces the osteochondrogenic transition of VSMC, by scavenging WNT5a, which attenuated SOX9 transcription [64]. Consequently, both factors are linked to VC. Besides, sFRP1 and sFRP2 suppress or activate WNT3a-mediated WNT/ $\beta$-catenin signaling depending on the ligandand receptor combination as well as the presence of WNT3a. For instance, increasing the availability of sFRP1, sFRP2, and WNT3a abolishes WNT/ $\beta$-catenin signaling when FZD5 is not expressed in the target cell or tissue [97]. In obese patients with atherosclerosis, however, the expression of FZD5 rises, potentially weakening the function of sFRP1 and sFRP2 as WNT/ $\beta$-catenin inhibitors [66]. As a consequence, their potential to attenuate $\mathrm{VC}$ in atherosclerosis may be impaired. 
Various clinical studies have found lower sFRP5 serum levels in obese, T2D, and CHD patients-all high-risk groups for VC-suggesting a critical function for sFRP5 in the healthy vasculature $[66,98,99]$. Moreover, increased WNT5a levels in obese patients were found, and some author suggested a link between SFRP5 and WNT5a in atherosclerosis $[66,100]$. It was further demonstrated that SFRP5 might inhibit WNT5a signaling, showing its potential to inhibit VC. In contrast, a recent publication found that WNT3a/ $\beta$-catenin signaling decreases in VSMC when treated with sFRP5, consequently attenuating RUNX2 expression. Thus, the osteochondrogenic de-differentiation of VSMC was impaired, and a potential role for sFRP5 in inhibiting VC by scavenging WNT3a was suggested [101]. However, this study could not confirm a direct interaction between Wnt3a and sFRP5. Considering the function of WNT5a in endochondral ossification, treatment of VSMC might has caused inhibition of WNT5a, which, consequently, would suppress the osteochondrogenic differentiation of VSMC.

Overall, since they are able to inhibit WNT5a/SOX9 as well as WNT/ $\beta$-catenin signal transduction, sFRPs may turn out as the first line of defense in VC. However, our understanding is still limited, and further studies are required to explain how the distribution of sFRP, FZD and WNT molecules in different cell types influence VC.

\section{Peroxisome Proliferator-Activated Receptor- $\gamma$ Signal Transduction}

PPAR $\gamma$ belongs to a family of nuclear receptors that includes the subtypes PPAR $\beta / \delta$ and PPAR $\alpha$. This receptor family coordinates a wide range of metabolic mechanisms like insulin sensitivity, glucose homeostasis and lipogenesis. PPAR $\gamma$, in particular, is the main determinant that regulates adipogenesis.

Naturally occurring polyunsaturated fatty acids like eicosapentaenoic acid (EPA) and synthetic ligands such as thiazolidinedione's (TZD) can directly activate PPAR $\gamma$. Subsequently, PPAR $\gamma$ forms a heterodimer with the retinoid $X$ receptor (RXR), and the resulting receptor complex binds to the PPAR-response element (PPRE) in the promoter region of numerous target genes, ultimately inducing their transcription. In contrast, target genes with PPRE binding sites can also be suppressed by the PPAR $\gamma-R X R$ complex as long as no ligand is available. Additionally, ligand-bound PPAR $\gamma$ binds, without RXR, to specific target sites to repress target genes [102,103].

\subsection{PPAR $\gamma$ Signaling in Atherosclerosis}

VSMC in the vasculature and macrophages express PPAR $\gamma$, indicating a role for PPAR $\gamma$ in vascular function, inflammation, and, consequently in vascular disease [104,105]. Indeed, suppression or deficiency of PPAR $\gamma$ is known to accelerate atherosclerotic lesion formation in different animal models. For instance, dominant-negative mutations of PPAR $\gamma$ in the aorta and VSMC lead to vascular dysfunction and hypertrophy in mice [104,105]. In atherosclerotic plaques of the arteria carotis, RXR $\alpha$ and PPAR $\gamma$ expression is reduced in the VSMC and macrophage cell populations [106]. The treatment with TZDs, on the other hand, reduces atherosclerotic plaque volume in $\mathrm{ApoE}^{-/-}$mice, New Zealand rabbits, as well as in CAD and T2D patients [107-110]. Even though these animal and clinical models differ significantly from each other, all studies concluded that the atherosclerotic plaque regression was due to PPAR $\gamma$ activation. Consequently, PPAR $\gamma$ seems essential for the healthy vasculature and PPAR $\gamma$ suppression may favor atherogenesis. The positive effects of PPAR $\gamma$ in atherosclerosis may occur due to its anti-inflammatory effects in the vasculature. Since inflammation and VC are strongly entangled, it stands to reason if the anti-inflammatory effects of PPAR $\gamma$ also attenuate VC by inhibiting the osteochondrogenic transition of VSMC.

In calcified radial arteries from CKD patients and calcified aortas from CKD mice, PPAR $\gamma$ expression decreases while osteochondrogenic VSMC cultured in high-phosphate or -glucose conditions present a similar outcome [111,112]. Concluding, that hyperphosphatemia and hyperglycemia, conditions commonly found in CKD and T2D, may attenuate PPAR $\gamma$ signal transduction in vivo, favoring VC. 


\subsection{PPAR $\gamma$ and the Vascular Calcification-Inflammation Axis}

High levels of pro-inflammatory cytokines such as TNF $\alpha$ and IL6 are frequently observed in $\mathrm{CKD}, \mathrm{T2D}$, and CAD patients, leading to chronic low-grade inflammation of the vasculature while also correlating with cardiovascular events [113-116]. Aforementioned in chapter 1.2, TNF $\alpha$, IL1 $\beta$, and IL6 are secreted by M1 macrophages. These cytokines favor the osteochondrogenic transition of VSMC and, consequently, the development of VC in mice [117-120]. Upon stimulation with a pro-inflammatory stimulus like Lipopolysaccharide, PPAR $\gamma$ deficiency increases TNF $\alpha$, IL1 $\beta$, and IL6 secretion in macrophages, an effect that indicates the transition to an M1 like phenotype [121]. On the other hand, PPAR $\gamma$ activation primes monocytes to undergo the transition to anti-inflammatory M2 macrophages, which are associated with plaque regression in CAD [44,122-124]. As a consequence, this may abolish the development of inflammation-mediated microcalcifications, hence, ensuring plaque stability. These evidences underline the importance of PPAR $\gamma$ in shaping the macrophage phenotype, making it a potential target to treat VC.

$\mathrm{TNF} \alpha$ is essential for the inflammatory response during atherogenesis, and various pro-atherosclerotic factors induce TNF $\alpha$ expression in macrophages, including TGF $\beta$, interferon- $\gamma$, as well as autocrine stimulation through TNF $\alpha$ itself [125]. In contrast to IL6, TNF $\alpha$ serum concentration does not correlate directly with CAC in CKD patients but both cytokines correlate positively, indicating interdependency [116]. The pro-osteogenic effects of TNF $\alpha$ seem to occur through the induction of IL6 via the c-FOS/activator protein-1/nuclear factor kappa-light-chain-enhancer of activated B cells (NF-KB) pathway in VSMC, which in turn accelerates the expression of RUNX2, ALP and other osteogenic factors [117]. However, early-stage T2D patients treated with TZD display a reduced TNF $\alpha$ and IL6 serum concentration, and monocytes react similarly to this treatment $[126,127]$. In conclusion, the mentioned data confirms the influence of inflammatory cytokines and the role of PPAR $\gamma$ suppression in VC by modifying the immune response of macrophages.

\subsection{Interplay of PPAR $\gamma$ Signaling with Other Signaling Pathways in Vascular Calcification}

The single transmembrane protein $\alpha$-Klotho is a phosphaturic protein essential for regulating mineral homeostasis and vitamin D metabolism. It is mainly expressed in the kidney and functions a co-receptor for fibroblast growth factor (FGF) 23 to promote binding to its target receptors. The membrane-bound $\alpha$-Klotho can be cleaved by secretases, leading to its secretion in blood, where it fulfills regulatory functions. A loss of $\alpha$-Klotho in mice is known to provoke a premature aging syndrome, which leads to the appearance of atherosclerosis, VC, and other age-related pathologies [128].

The chronically high concentration of pro-inflammatory cytokines like IL6 and TNF $\alpha$ found in atherosclerosis and T2D attenuates renal and vascular Klotho expression by increasing FGF23 concentration through the NF-kB pathway [128-130]. This finding links chronic low-grade inflammation to $\alpha$-Klotho deficiency, highlighting its relevance for VC.

During CKD progression, secreted $\alpha$-Klotho concentration decreases, ultimately leading to hyperphosphatemia and VC $[128,131,132]$. This decrease of $\alpha$-Klotho is due to a pathological increase in FGF23, parathyroid hormone, and low vitamin D levels, a deteriorated serum profile that frequently occurs as CKD progresses [128]. Similar effects are observed when VSMC were calcified under high-phosphate conditions, leading to $\alpha$-Klotho deficiency accompanied by an increase of inorganic phosphate transporter (PIT) 1 and 2 expression-transporter proteins essential for $P_{i}$ influx in VSMC - indicating an interdependency of VC and hyperphosphatemia [111,132,133]. However, mice fed a high-fat diet (HFD) display no change in phosphate serum concentration but increased TNF $\alpha$ and FGF23 [134]. Similarly, in rats fed HFD, phosphate restriction did not improve the FGF23 or secreted $\alpha$-Klotho serum profile [135]. These observations were further evidenced in HFD fed rabbits, which displayed a decreased $\alpha$-Klotho expression accompanied by an upregulation of calcification markers like OPG and OPN, as well as an imbalance of different transporter proteins such as PIT1 and enzymes responsible for the regulation of a healthy inorganic phosphate and pyrophosphate ratio [136]. Consequently, the serum phosphate concentration alone, probably, does not predict VC, but rather 
the ratio of inorganic phosphate and the calcification inhibitor pyrophosphate. Overexpression of $\alpha$-Klotho, on the other hand, abolishes the osteochondrogenic transition of VSMC by downregulating PIT1 and PIT2, effects that were also achieved with PPAR $\gamma$ agonists achieved in CKD mice $[111,132,137]$.

The acetylation of PPAR $\gamma$ is essential to regulate the transcription of various target genes. However, histone deacetylases (HDAC) like HDAC3 are upregulated in mice with CKD, leading to the suppression of PPAR $\gamma$ activity through de-acetylation, which may explain the $\alpha$-Klotho deficiency in CKD [138]. Consequently, PPAR $\gamma$ activation during atherogenesis may upregulate $\alpha$-Klotho to interfere with the osteochondrogenic changes of VSMC.

Activation of PPAR $\gamma$ also suppresses the renin angiotensin aldosterone system (RAAS) $[128,139]$. The RAAS is associated with hypertension, vascular dysfunction, and an $\alpha$-Klotho inhibitor. A recently published study suggested crosstalk between PPAR $\gamma$, RAS, and Klotho in a CKD animal model and MDCK cells [140]. Still, the impact of the RAAS on VC is unclear, but current advances show that mice, over-expressing the angiotensin type 2 receptor in VSMC, display a higher PPAR $\gamma$ activity and were less susceptible to VC. Additionally, the PPAR $\gamma$ antagonist GW9662 attenuated the effects of angiotensin type 2 receptor overexpression and PPAR $\gamma$ activity in rats and VSMC [141,142]. Despite the clear connection between Klotho, PPAR $\gamma$, and VC, further research is needed to understand the involvement of the RAAS.

\section{The Interplay between PPAR $\gamma$ and WNT Signaling in Vascular Calcification}

The following free and Mesh search terms were used to identify peer reviewed articles in English through the electronic databases PubMed and PMC: "ppar gamma" AND "vascular calcification" AND "Wnt". Reviews, Editorials and conference abstracts were excluded. In addition, all studies were excluded that did not show any relations to WNT and PPAR $\gamma$ in the context of VC. Searches were performed on 10 July 2020 (Figure A1) and in total four studies (Woldt et al.; Zhou et al.; Gao et al.; and Saito et al.) were included.

The suppression of PPAR $\gamma$, is fundamental for the osteogenic lineage determination of MSC [27,48]. However, the differentiation from MSC to osteoblasts requires WNT/ $\beta$-catenin signaling activity, mediated by ligands like WNT10b [143]. The higher WNT/ $\beta$-catenin signaling activity attenuates PPAR $\gamma$ signal transduction via $\beta$-catenin stabilization and transcriptional targets like cyclin D1 [143-146]. This relationship has received growing attention over the past years, especially in MSC, and some authors already reported a differential expression of the WNT/ $\beta$-catenin pathway and PPAR $\gamma$ in the atherosclerotic plaque $[48,147]$. Literature about the crosstalk between $\beta$-catenin independent WNT signaling and PPAR $\gamma$, however, remained scarce and was covered by just a few studies. In VC, it remains unclear if and how these pathways are interconnected, questioning if $\mathrm{VC}$ partly result from a dysfunctional interplay between WNT and PPAR $\gamma$ signal transduction.

\subsection{PPAR $\gamma$ Signaling Crosstalk with the Non- $\beta$-Catenin-Mediated WNT Signaling Pathway}

A PPAR $\gamma$ and $\beta$-catenin independent WNT signaling interplay was first evidenced by Woldt et al. In their study, PPAR $\gamma$ deficiency in VSMC of LDLR ${ }^{-/-}$mice increased VC, which was accompanied by an increased SOX9 and RUNX2 expression [64]. In accordance with studies on chondrogenic precursor cells, the study demonstrated that WNT5a induces SOX9 expression, initiating the stage-dependent, osteochondrogenic differentiation of VSMC [52,64]. The deletion or suppression of LRP1—a receptor essential for early chondrogenesis-was associated with the absence of calcified lesions and a decreased WNT5a expression in the vessel wall in mice, indicating a function for LRP1 in VC by upregulating WNT5a expression $[64,148]$. This LRP1-WNT5a link was also evidenced in fibroblasts, where TGF $\beta$ treatment-a factor known to originate from the injured vessel wall—of LRP1-deficient fibroblasts did not induce WNT5a transcription and provoked a considerably lower protein induction than found in control fibroblasts [149-151]. Notably, TGF $\beta$ is also a well-known ligand for LRP1, where it plays a role in fibroblast activation and ECM synthesis [152]. Further, TGF $\beta$ promotes osteogenesis and migration of MSC, while also inducing osteochondrogenic effects on VSMC. Therefore, a hypothetical 
TGF $\beta /$ LRP1/WNT5a/NF-AT/SOX9 signaling cascade could set the stage for VSMC-mediated VC (Figure 2A) [28,153].

This cascade may be inhibited by the activation of PPAR $\gamma$ via the upregulation of the WNT5a scavenger's sFRP2 and sFRP5 $[64,154]$. Current advances demonstrated that sFRP5 seems to attenuate the osteochondrogenic transition of VSMC through the inhibition of WNT/ $\beta$-catenin signaling (as discussed in Section 2.3) [95,101]. However, sFRP5 inhibits WNT5a signal transduction in adipose tissue and macrophages, hindering inflammation and macrophage activation $[155,156]$. Consequently, sFRP5 possibly also inhibits WNT5a in osteochondrogenic VSMC. However, calcified VSMC displayed a low WNT5a and sFRP5 expression [95]. This appears contradictive at first, but indeed is comparable to endochondral ossification, during which WNT5a initiates the chondrogenic transition, but must be inhibited to complete the remaining osteogenic program. The demonstration for this sequential mechanism, however, is missing in the study reviewed. This highlights the obligation to perform longitudinal studies to investigate the time-dependent character of molecular signaling events in VC. Beyond the local impact of sFRPs mediated via PPAR $\gamma$ activation on VSMC, a recent study has evidenced the ability of sFRP5 to directly interact with LRP1 in macrophages in pro-inflammatory conditions. Thereby, it induces its proteasomal degradation, as suggested by the authors [157]. This may result in increased availability of WNT5a originating from macrophages, which might promote the osteochondrogenic transition of VSMC in the atherosclerotic plaque.

\subsection{The Effects of PPAR $\gamma$ Signaling on $\beta$-Catenin-Mediated WNT Signaling}

PPAR $\gamma$ may also interfere with the pro-osteogenic effects of $\mathrm{WNT} / \beta$-catenin signaling (Figure 3). The activation of PPAR $\gamma$ inhibits the osteogenic transition of MSC by interfering with RUNX2 expression and collagen deposition and comparable results were reported in osteochondrogenic VSMC of the rat $[158,159]$. Gao et al. demonstrated that the calcium deposition as well as RUNX2, $\beta$-catenin, and Cyclin-D1 expression was decreased after treatment with Pioglitazone [160]. Similarly, Zhou et al. obtained comparable results with the PPAR $\gamma$ agonist ginsenoside Rb1 (GRb1) in osteochondrogenic VSMC [161-163]. In the control group, a decreased expression of the contractile markers calponin-1 and ACTA2 as well as an increased expression of RUNX2, accompanied by high $\beta$-catenin activity was observed. This indicates the phenotypic transition of the VSMC to an osteochondrogenic phenotype. However, treatment with GRb1 attenuated the osteochondrogenic transition and increased PPAR $\gamma$ expression, whereas a PPAR $\gamma$ antagonist reversed these effects. The authors concluded that PPAR $\gamma$ mediated these anti-osteogenic effects, demonstrating a PPAR $\gamma$ and WNT/ $\beta$-catenin crosstalk of relevance for VC [163]. Other PPAR $\gamma$ agonists, such as the omega-3-fatty acid EPA—as described by Saito et al. and others-are also known to reduce VC in different rodent models [164-167].

Aforementioned in Section 2.3, $\alpha$-Klotho is a transcriptional target of PPAR $\gamma$. Moreover, $\mathrm{Klotho}^{-/-}$ mice display a high expression of $\beta$-catenin in the aorta [165]. These findings may indicate that Klotho inhibits the WNT/ $\beta$-catenin pathway in VC and, indeed, secreted $\alpha$-Klotho sequesters $\mathrm{WNT} / \beta$-catenin ligands; consequently, inhibiting WNT/ $\beta$-catenin signal transduction $[168,169]$. In human VSMC, EPA abolishes WNT3a-induced osteochondrogenic changes by decreasing RUNX2 and increasing PPAR $\gamma$ expression [165]. Hence, EPA may attenuate VC by acting on PPAR $\gamma$ to inhibit $W N T / \beta$-catenin activity through the upregulation of Klotho. However, $\alpha$-Klotho also attenuates PIT1 and PIT2 gene expression-Phosphate transporters, which are essential for the osteochondrogenic transition of VSMC [132]. Consequently, the effects found in this study could be partly initiated through a downregulation of PIT1 and 2.

Besides the transcription of $\alpha$-Klotho, PPAR $\gamma$ may induce activation of the WNT/ $\beta$-catenin inhibitor GSK3 $\beta$, and the transcription of DKK1 $[160,170,171]$. The latter observations were obtained in adipocytes, making a direct translation to VSMC difficult. However, the used cell types originate from MSC, which could hint to a similar conserved pathway in VSMC. Moreover, GSK3 $\beta$ activity in the $\beta$-catenin destruction complex does not depend on its serine or tyrosine phosphorylation, still this 
measurement was used in this study to determine GSK3 $\beta$-activity. Consequently, it is not clear if these effects were related to PPAR $\gamma[160,172]$.

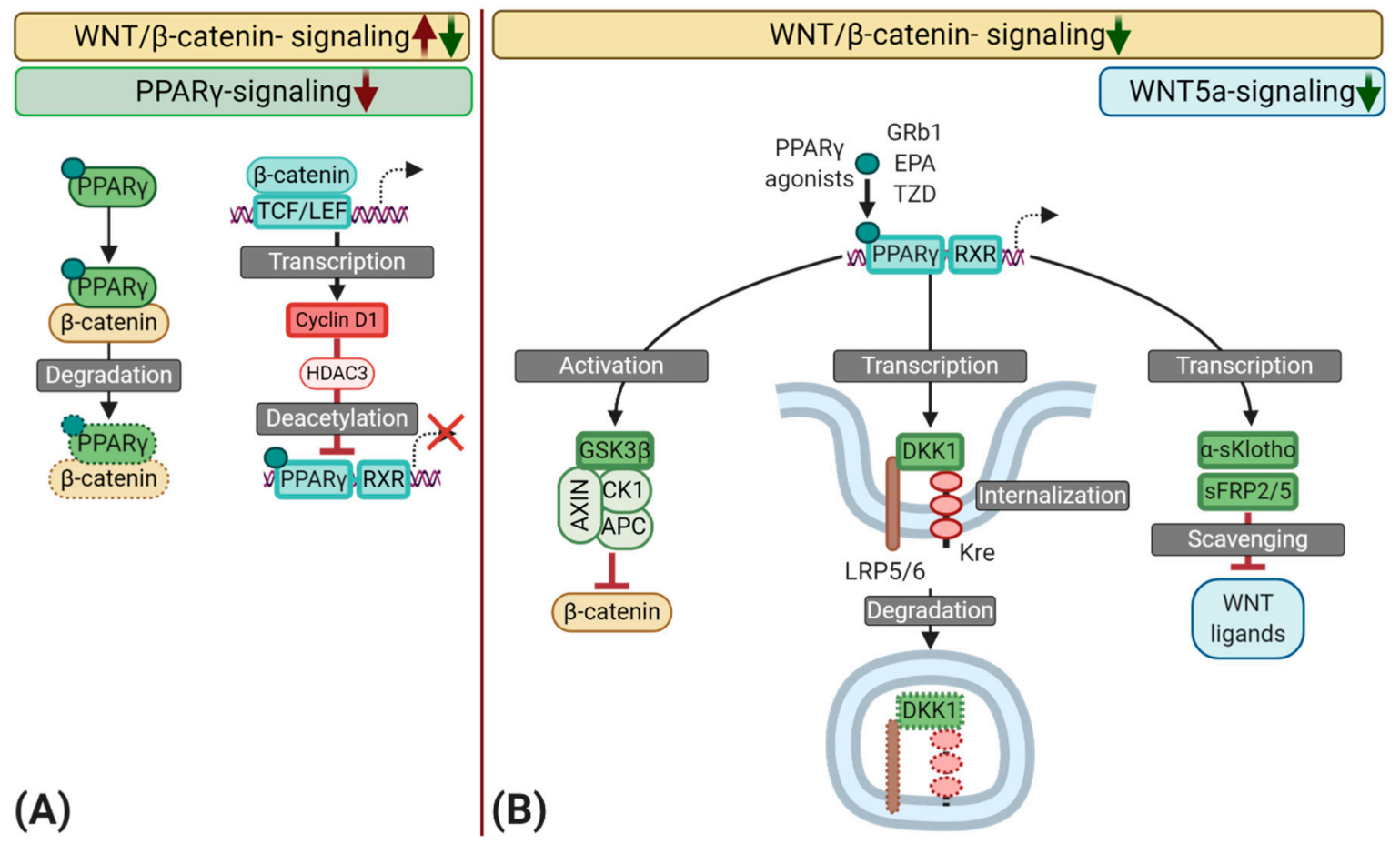

Figure 3. Schematic representation of the interplay between peroxisome proliferator-activated receptor $\gamma(\mathrm{PPAR} \gamma)$ and the Wingless and Int-1 (WNT) signaling pathways during vascular calcification (VC) with a focus on the osteochondrogenic transition of synthetic vascular smooth muscle cells (VSMC). (A) Several mechanisms may inhibit PPAR $\gamma$ signaling during atherogenesis. First, ligand-bound PPAR $\gamma$ may sequester $\beta$-catenin, leading to the proteasomal degradation of this complex. As a result, a high activation of the WNT/ $\beta$-catenin pathway could reduce PPAR $\gamma$ availability and vice versa. Second, WNT/ $\beta$-catenin signaling induces the transcription of Cyclin D1, which promotes the recruitment of Histone deacetylase 3 (HDAC3) to PPAR $\gamma$, inducing deacetylation, consequently, reducing the transcriptional activity of PPAR $\gamma$. (B) Various naturally occurring compounds such as polyunsaturated fatty acids like eicosapentaenoic acid (EPA) and the ginsenoside Rb1 (GRb1), as well as synthetic compounds like Thiazolidines (TZD), can directly activate PPAR $\gamma$. Upon activation, PPAR $\gamma$ interacts with retinoid-x-receptors (RXR) to induce the transcription of target genes. PPAR $\gamma$ may dimmish WNT/ $\beta$-catenin signaling through the activation of glycogen synthase kinase-three- $\beta$ (GSK3 $\beta$ ) - an essential part of the $\beta$-catenin destruction complex. Moreover, PPAR $\gamma$ induces the transcription of WNT scavengers like secreted frizzled-related protein 2 and 5 (sFRP2/5), as well as secreted $\alpha$-Klotho ( $\alpha$-sKlotho), which results in an inhibition of SOX9 and RUNX2 by scavenging WNT ligands such as WNT5a and WNT3a. The binding of dickkopf-1 (DKK1), another transcriptional target of PPAR $\gamma$, to lipoprotein receptor-related protein 5 or 6 (LRP5/6) leads to a complex formation with the Kremen receptor (Kre), followed by its internalization and degradation, ultimately inhibiting Wnt/ $\beta$-catenin signal transduction.

Beyond these previous observations, ligand-bound PPAR $\gamma$ may sequester $\beta$-catenin through its TCF/LEF binding domain and a catenin binding domain, a process that may occur GSK3 $\beta$-mediated and -independent as well, leading to the proteasomal degradation of this complex via ubiquitination [173175]. Given the delicate balance between WNT and PPAR $\gamma$ in VC, this could be a double-edged sword, since a high activation of the WNT/ $\beta$-catenin pathway, as found in atherosclerosis, could reduce PPAR $\gamma$ availability, shifting the balance towards a pathologically high $\beta$-catenin concentration. Furthermore, oncogenic forms of $\beta$-catenin show resistance towards the $\beta$-catenin destruction complex and inhibit binding of $\operatorname{PPAR} \gamma$, questioning the presence of similar mutations in atherosclerotic lesions [174]. 
The WNT/ß-catenin signaling target Cyclin D1 initiates the recruitment of HDAC3 to PPAR $\gamma$, leading to the de-acetylation of PPAR $\gamma$, ultimately suppressing target gene transcription [144]. Notably, HDAC 3 expression is increased by inflammatory factors like TNF $\alpha$ and inhibiting HDAC1 and -3 with MS-275 attenuates calcification of valvular interstitial cells, accompanied by a reduced WNT/ $\beta$-catenin signaling activity and RUNX2 expression [176,177]. However, the effect of this HDAC Inhibitor is not specific and inhibits other HDACs like HDAC1, which may inhibit VC in specific settings [178]. Regardless, it stays questionable if the described mechanisms are similar in VSMC.

\section{Conclusions}

In this review, we described how the sequential activation of WNT5a-signaling, the $W N T / \beta$-catenin pathway and the dysregulation of PPAR $\gamma$ during atherogenesis, is involved in VC by guiding the osteochondrogenic transition of VSMCs. Plaque topography, disease etiology, as well as cell heterogeneity and the complexity of the underlying mechanisms make it essential to investigate these fundamental molecular pathways further. The resulting insights may clarify the relationship of macrophages and VSMC during VC, by identifying key factors relevant for the induction of WNT signaling in atherosclerotic plaques. Besides some new, experimental, pharmaceuticals like the RANKL inhibitor Denosumab, no commercial drug affects the main cause of $\mathrm{VC}$, namely the osteochondrogenic differentiation of VSMC. Therefore, already registered PPAR $\gamma$ agonists may deserve more attention as potential VC inhibitors for patients at the onset of atherosclerosis due to their anti-inflammatory and cell fate modulating properties.

Author Contributions: Conceptualization, S.R., W.M.B., and S.F.; Methodology, S.R., W.M.B., and S.F.; writing-original draft preparation, S.R.; writing—review and editing, S.R., W.M.B., and S.F.; illustrations, S.R.; and supervision, W.M.B., and S.F. All authors have read and agreed to the published version of the manuscript.

Funding: This research has received funding from the European Union's Horizon 2020 research and innovation programme under the Marie Skłodowska-Curie grant agreement No 722609.

Acknowledgments: Figures 1-3 were created using BioRender (http://biorender.com/).

Conflicts of Interest: The authors declare no conflict of interest.

$\begin{array}{ll}\text { Abbreviations } & \\ \text { ACAN } & \text { Aggrecan } \\ \text { ACTA2 } & \alpha \text {-smooth muscle actin } \\ \text { AIC } & \text { arterial intimal calcification } \\ \text { ALP } & \text { Alkaline phosphatase } \\ \text { AMC } & \text { arterial medial calcification } \\ \text { APC } & \text { Adenomatous polyposis coli } \\ \text { BMP } & \text { Bone morphogenetic protein } \\ \text { CAC } & \text { Coronary artery calcification } \\ \text { CaN } & \text { Calcineurin } \\ \text { CHD } & \text { Coronary heart disease } \\ \text { CK1 } & \text { Casein Kinase-1 } \\ \text { CKD } & \text { Chronic kidney disease } \\ \text { COL2A1 } & \text { collagen type II alpha } \\ \text { CVD } & \text { Cardiovascular disease } \\ \text { DKK } & \text { Dickkopf } \\ \text { ECM } & \text { Extracellular matrix } \\ \text { FGF } & \text { Fibroblast growth factor } \\ \text { FZD } & \text { Frizzled receptor } \\ \text { GRb1 } & \text { Ginsenoside Rb1 } \\ \text { GSK3 } \beta & \text { Glycogen synthase kinase 3- } \beta \\ \text { HDAC } & \text { Histone deacetylase } \\ \text { HFD } & \text { High-fat diet } \\ & \end{array}$


IL

Kre

LRP5/6

MSC

MMP13

NF-AT

NF-KB

OCN

OPG

OPN

OSX

oxLDL

PIT

PPAR $\gamma$

PPRE

RANKL

RUNX2

RAAS

RXR

sFRP

SOX9

T1D

T2D

TCF/LEF

TGF $\beta$

$\mathrm{TNF} \alpha$

TRAIL

VC

VSMC

WNT
Interleukin

Kremen

Lipoprotein receptor-related protein 5/6

Mesenchymal stem cells

Matrix metalloprotease 13

nuclear factor of activated T-cells

kappa-light-chain-enhancer of activated B cells

Osteocalcin

Osteoprotegerin

Osteopontin

Osterix

oxidized low density lipoprotein

inorganic phosphate transporter

Peroxisome proliferator-activated receptor $\gamma$

PPAR response element

receptor activator of nuclear factor- $\mathrm{kB}$ ligand

Runt-related transcription factor 2

Renin angiotensin aldosterone system

Retinoid X receptor

secreted frizzled receptor protein

SRY-box transcription factor 9

Type 1 Diabetes

Type 2 Diabetes

T-cell factor/lymphoid enhancer-binding factor

Transforming growth factor $\beta$

Tumor necrosis factor $\alpha$

TNF-related apoptosis-inducing ligand

Vascular calcification

Vascular smooth muscle cells

Wingless/Int-1

\section{Appendix A}

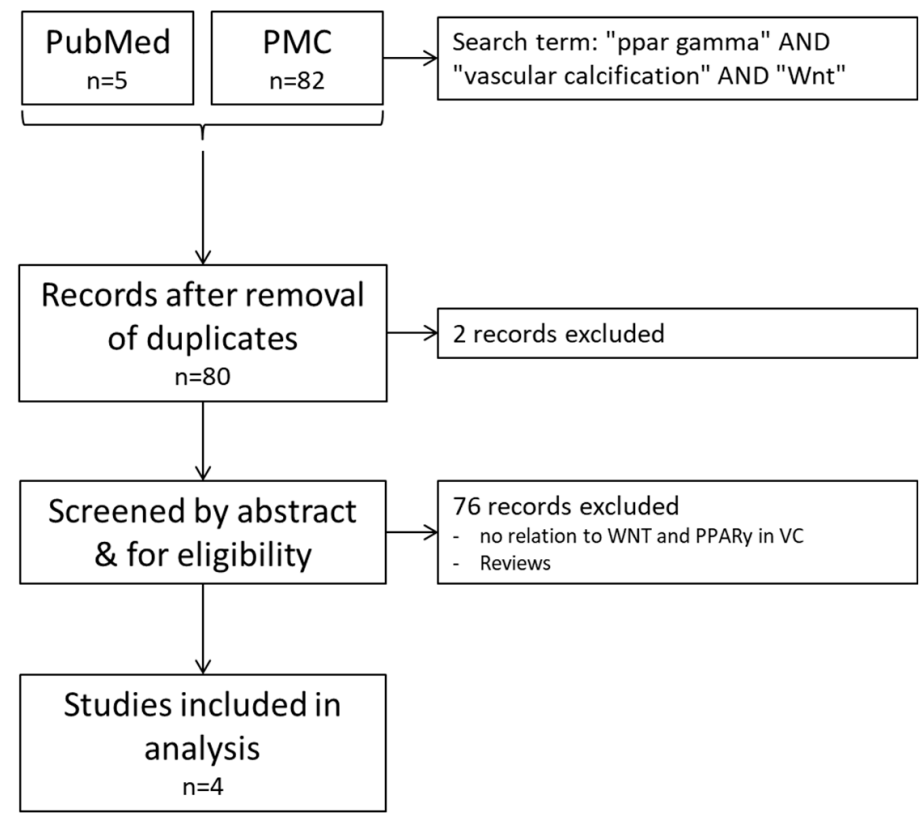

Figure A1. Flow chart to illustrate the systematic search protocol to identify relevant literature in the PubMed and PMC databases. 


\section{References}

1. Roth, G.A.; Johnson, C.; Abajobir, A.; Abd-Allah, F.; Abera, S.F.; Abyu, G.; Ahmed, M.; Aksut, B.; Alam, T.; Alam, K.; et al. Global, Regional, and National Burden of Cardiovascular Diseases for 10 Causes, 1990 to 2015. J. Am. Coll. Cardiol. 2017, 70, 1-25. [CrossRef]

2. Benjamin, E.J.; Muntner, P.; Alonso, A.; Bittencourt, M.S.; Callaway, C.W.; Carson, A.P.; Chamberlain, A.M.; Chang, A.R.; Cheng, S.; Das, S.R.; et al. Heart Disease and Stroke Statistics-2019 Update: A Report From the American Heart Association. Circulation 2019, 139, e56-e528. [CrossRef]

3. Bloom, D.E.; Cafiero, E.T.; Jané-Llopis, E.; Abrahams-Gessel, S.; Bloom, L.R.; Fathima, S.; Feigl, A.B.; Gaziano, T.; Mowafi, M.; Pandya, A.; et al. The Global Economic Burden of Noncommunicable Diseases; World Economic Forum: Geneva, Switzerland, 2011.

4. Bild, D.E.; Detrano, R.; Peterson, D.; Guerci, A.; Liu, K.; Shahar, E.; Ouyang, P.; Jackson, S.; Saad, M.F. Ethnic differences in coronary calcification: The Multi-Ethnic Study of Atherosclerosis (MESA). Circulation 2005, 111, 1313-1320. [CrossRef] [PubMed]

5. Detrano, R.; Guerci, A.D.; Carr, J.J.; Bild, D.E.; Burke, G.; Folsom, A.R.; Liu, K.; Shea, S.; Szklo, M.; Bluemke, D.A.; et al. Coronary calcium as a predictor of coronary events in four racial or ethnic groups. N. Engl. J. Med. 2008, 358, 1336-1345. [CrossRef] [PubMed]

6. Rennenberg, R.J.; Kessels, A.G.; Schurgers, L.J.; van Engelshoven, J.M.; de Leeuw, P.W.; Kroon, A.A. Vascular calcifications as a marker of increased cardiovascular risk: A meta-analysis. Vasc. Health Risk Manag. 2009, 5, 185-197. [CrossRef] [PubMed]

7. Jha, V.; Garcia-Garcia, G.; Iseki, K.; Li, Z.; Naicker, S.; Plattner, B.; Saran, R.; Wang, A.Y.; Yang, C.W. Chronic kidney disease: Global dimension and perspectives. Lancet 2013, 382, 260-272. [CrossRef]

8. Kaplan,H.; Thompson, R.C.; Trumble, B.C.; Wann, L.S.; Allam, A.H.; Beheim, B.; Frohlich, B.; Sutherland, M.L.; Sutherland, J.D.; Stieglitz, J.; et al. Coronary atherosclerosis in indigenous South American Tsimane: A cross-sectional cohort study. Lancet 2017, 389, 1730-1739. [CrossRef]

9. Aengevaeren, V.L.; Mosterd, A.; Sharma, S.; Prakken, N.H.J.; Mohlenkamp, S.; Thompson, P.D.; Velthuis, B.K.; Eijsvogels, T.M.H. Exercise and Coronary Atherosclerosis: Observations, Explanations, Relevance, and Clinical Management. Circulation 2020, 141, 1338-1350. [CrossRef]

10. Mori, H.; Torii, S.; Kutyna, M.; Sakamoto, A.; Finn, A.V.; Virmani, R. Coronary Artery Calcification and its Progression: What Does it Really Mean? JACC Cardiovasc. Imaging 2018, 11, 127-142. [CrossRef]

11. Rutkovskiy, A.; Stenslokken, K.O.; Vaage, I.J. Osteoblast Differentiation at a Glance. Med. Sci. Monit. Basic Res. 2016, 22, 95-106. [CrossRef]

12. Houben, E.; Neradova, A.; Schurgers, L.J.; Vervloet, M. The influence of phosphate, calcium and magnesium on matrix Gla-protein and vascular calcification: A systematic review. Giornale Italiano di Nefrologia 2016, 33, 1724-5590.

13. Brylka, L.; Jahnen-Dechent, W. The role of fetuin-A in physiological and pathological mineralization. Calcif. Tissue Int. 2013, 93, 355-364. [CrossRef] [PubMed]

14. Florea, A.; Morgenroth, A.; Bucerius, J.; Schurgers, L.J.; Mottaghy, F.M. Locking and loading the bullet against micro-calcification. Eur. J. Prev. Cardiol. 2020. [CrossRef] [PubMed]

15. Mitchell, G.F. Arterial stiffness and hypertension: Chicken or egg? Hypertension 2014, 64, 210-214. [CrossRef]

16. Chen, Y.; Zhao, X.; Wu, H. Arterial Stiffness: A Focus on Vascular Calcification and Its Link to Bone Mineralization. Arterioscler. Thromb. Vasc. Biol. 2020, 40, 1078-1093. [CrossRef] [PubMed]

17. Akers, E.J.; Nicholls, S.J.; Di Bartolo, B.A. Plaque Calcification: Do Lipoproteins Have a Role? Arterioscler. Thromb. Vasc. Biol. 2019, 39, 1902-1910. [CrossRef] [PubMed]

18. Vossen, L.M.; Kroon, A.A.; Schurgers, L.J.; de Leeuw, P.W. Pharmacological and Nutritional Modulation of Vascular Calcification. Nutrients 2019, 12, 100. [CrossRef]

19. Nicholls, S.J.; Puri, R.; Anderson, T.; Ballantyne, C.M.; Cho, L.; Kastelein, J.J.P.; Koenig, W.; Somaratne, R.; Kassahun, H.; Yang, J.; et al. Effect of Evolocumab on Coronary Plaque Composition. J. Am. Coll. Cardiol. 2018, 72, 2012-2021. [CrossRef]

20. Sulkava, M.; Raitoharju, E.; Levula, M.; Seppala, I.; Lyytikainen, L.P.; Mennander, A.; Jarvinen, O.; Zeitlin, R.; Salenius, J.P.; Illig, T.; et al. Differentially expressed genes and canonical pathway expression in human atherosclerotic plaques-Tampere Vascular Study. Sci. Rep. 2017, 7, 41483. [CrossRef] 
21. Espitia, O.; Chatelais, M.; Steenman, M.; Charrier, C.; Maurel, B.; Georges, S.; Houlgatte, R.; Verrecchia, F.; Ory, B.; Lamoureux, F.; et al. Implication of molecular vascular smooth muscle cell heterogeneity among arterial beds in arterial calcification. PLoS ONE 2018, 13, e0191976. [CrossRef]

22. Leroux-Berger, M.; Queguiner, I.; Maciel, T.T.; Ho, A.; Relaix, F.; Kempf, H. Pathologic calcification of adult vascular smooth muscle cells differs on their crest or mesodermal embryonic origin. J. Bone Min. Res. 2011, 26, 1543-1553. [CrossRef] [PubMed]

23. Yahagi, K.; Kolodgie, F.D.; Lutter, C.; Mori, H.; Romero, M.E.; Finn, A.V.; Virmani, R. Pathology of Human Coronary and Carotid Artery Atherosclerosis and Vascular Calcification in Diabetes Mellitus. Arterioscler. Thromb. Vasc. Biol. 2017, 37, 191-204. [CrossRef] [PubMed]

24. Jaminon, A.; Reesink, K.; Kroon, A.; Schurgers, L. The Role of Vascular Smooth Muscle Cells in Arterial Remodeling: Focus on Calcification-Related Processes. Int. J. Mol. Sci. 2019, 20, 5694. [CrossRef] [PubMed]

25. Basatemur, G.L.; Jorgensen, H.F.; Clarke, M.C.H.; Bennett, M.R.; Mallat, Z. Vascular smooth muscle cells in atherosclerosis. Nat. Rev. Cardiol. 2019, 16, 727-744. [CrossRef] [PubMed]

26. Hortells, L.; Sur, S.; St Hilaire, C. Cell Phenotype Transitions in Cardiovascular Calcification. Front. Cardiovasc. Med. 2018, 5, 27. [CrossRef] [PubMed]

27. Chen, Q.; Shou, P.; Zheng, C.; Jiang, M.; Cao, G.; Yang, Q.; Cao, J.; Xie, N.; Velletri, T.; Zhang, X.; et al. Fate decision of mesenchymal stem cells: Adipocytes or osteoblasts? Cell Death Differ. 2016, 23, 1128-1139. [CrossRef]

28. Xie, C.; Ouyang, L.; Chen, J.; Zhang, H.; Luo, P.; Wang, J.; Huang, H. The Emerging Role of Mesenchymal Stem Cells in Vascular Calcification. Stem Cells Int. 2019, 2019, 2875189. [CrossRef]

29. Steenman, M.; Espitia, O.; Maurel, B.; Guyomarch, B.; Heymann, M.F.; Pistorius, M.A.; Ory, B.; Heymann, D.; Houlgatte, R.; Goueffic, Y.; et al. Identification of genomic differences among peripheral arterial beds in atherosclerotic and healthy arteries. Sci. Rep. 2018, 8, 3940. [CrossRef]

30. Xin, H.; Xin, F.; Zhou, S.; Guan, S. The Wnt5a/Ror2 pathway is associated with determination of the differentiation fate of bone marrow mesenchymal stem cells in vascular calcification. Int. J. Mol. Med. 2013, 31, 583-588. [CrossRef]

31. Augstein, A.; Mierke, J.; Poitz, D.M.; Strasser, R.H. Sox9 is increased in arterial plaque and stenosis, associated with synthetic phenotype of vascular smooth muscle cells and causes alterations in extracellular matrix and calcification. Biochim. Biophys. Acta Mol. Basis Dis. 2018, 1864, 2526-2537. [CrossRef]

32. Tyson, K.L.; Reynolds, J.L.; McNair, R.; Zhang, Q.; Weissberg, P.L.; Shanahan, C.M. Osteo/chondrocytic transcription factors and their target genes exhibit distinct patterns of expression in human arterial calcification. Arterioscler. Thromb. Vasc. Biol. 2003, 23, 489-494. [CrossRef]

33. Lin, M.E.; Chen, T.M.; Wallingford, M.C.; Nguyen, N.B.; Yamada, S.; Sawangmake, C.; Zhang, J.; Speer, M.Y.; Giachelli, C.M. Runx2 deletion in smooth muscle cells inhibits vascular osteochondrogenesis and calcification but not atherosclerotic lesion formation. Cardiovasc. Res. 2016, 112, 606-616. [CrossRef] [PubMed]

34. Bobryshev, Y.V. Transdifferentiation of smooth muscle cells into chondrocytes in atherosclerotic arteries in situ: Implications for diffuse intimal calcification. J. Pathol. 2005, 205, 641-650. [CrossRef] [PubMed]

35. Mir, B.; Goettsch, C. Extracellular Vesicles as Delivery Vehicles of Specific Cellular Cargo. Cells 2020, 9, 1601. [CrossRef]

36. Boere, J.; Malda, J.; van de Lest, C.H.A.; van Weeren, P.R.; Wauben, M.H.M. Extracellular Vesicles in Joint Disease and Therapy. Front. Immunol. 2018, 9, 2575. [CrossRef]

37. Alves, R.D.; Eijken, M.; van de Peppel, J.; van Leeuwen, J.P. Calcifying vascular smooth muscle cells and osteoblasts: Independent cell types exhibiting extracellular matrix and biomineralization-related mimicries. BMC Genom. 2014, 15, 965. [CrossRef]

38. Azpiazu, D.; Gonzalo, S.; Gonzalez-Parra, E.; Egido, J.; Villa-Bellosta, R. Role of pyrophosphate in vascular calcification in chronic kidney disease. Nefrologia 2018, 38, 250-257. [CrossRef]

39. Patel, J.J.; Bourne, L.E.; Davies, B.K.; Arnett, T.R.; MacRae, V.E.; Wheeler-Jones, C.P.; Orriss, I.R. Differing calcification processes in cultured vascular smooth muscle cells and osteoblasts. Exp. Cell Res. 2019, 380, 100-113. [CrossRef]

40. Bobryshev, Y.V.; Nikiforov, N.G.; Elizova, N.V.; Orekhov, A.N. Macrophages and Their Contribution to the Development of Atherosclerosis. Results Probl. Cell Differ. 2017, 62, 273-298. [CrossRef]

41. Shioi, A.; Ikari, Y. Plaque Calcification During Atherosclerosis Progression and Regression. J. Atheroscler. Thromb. 2018, 25, 294-303. [CrossRef] 
42. Ceneri, N.; Zhao, L.; Young, B.D.; Healy, A.; Coskun, S.; Vasavada, H.; Yarovinsky, T.O.; Ike, K.; Pardi, R.; Qin, L.; et al. Rac2 Modulates Atherosclerotic Calcification by Regulating Macrophage Interleukin-1beta Production. Arterioscler. Thromb. Vasc. Biol. 2017, 37, 328-340. [CrossRef]

43. Smith, E.R.; Hanssen, E.; McMahon, L.P.; Holt, S.G. Fetuin-A-containing calciprotein particles reduce mineral stress in the macrophage. PLoS ONE 2013, 8, e60904. [CrossRef]

44. Bi, Y.; Chen, J.; Hu, F.; Liu, J.; Li, M.; Zhao, L. M2 Macrophages as a Potential Target for Antiatherosclerosis Treatment. Neural Plast. 2019, 2019, 6724903. [CrossRef]

45. New, S.E.; Goettsch, C.; Aikawa, M.; Marchini, J.F.; Shibasaki, M.; Yabusaki, K.; Libby, P.; Shanahan, C.M.; Croce, K.; Aikawa, E. Macrophage-derived matrix vesicles: An alternative novel mechanism for microcalcification in atherosclerotic plaques. Circ. Res. 2013, 113, 72-77. [CrossRef]

46. Bakhshian Nik, A.; Hutcheson, J.D.; Aikawa, E. Extracellular Vesicles As Mediators of Cardiovascular Calcification. Front. Cardiovasc. Med. 2017, 4, 78. [CrossRef]

47. Rochette, L.; Meloux, A.; Rigal, E.; Zeller, M.; Malka, G.; Cottin, Y.; Vergely, C. The Role of Osteoprotegerin in Vascular Calcification and Bone Metabolism: The Basis for Developing New Therapeutics. Calcif. Tissue Int. 2019, 105, 239-251. [CrossRef]

48. Yuan, Z.; Li, Q.; Luo, S.; Liu, Z.; Luo, D.; Zhang, B.; Zhang, D.; Rao, P.; Xiao, J. PPARgamma and Wnt Signaling in Adipogenic and Osteogenic Differentiation of Mesenchymal Stem Cells. Curr. Stem Cell Res. 2016, 11, 216-225. [CrossRef]

49. Nusse, R.; Varmus, H.E. Many tumors induced by the mouse mammary tumor virus contain a provirus integrated in the same region of the host genome. Cell 1982, 31, 99-109. [CrossRef]

50. Hrckulak, D.; Kolar, M.; Strnad, H.; Korinek, V. TCF/LEF Transcription Factors: An Update from the Internet Resources. Cancers 2016, 8,70. [CrossRef]

51. Foulquier, S.; Daskalopoulos, E.P.; Lluri, G.; Hermans, K.C.M.; Deb, A.; Blankesteijn, W.M. WNT Signaling in Cardiac and Vascular Disease. Pharm. Rev. 2018, 70, 68-141. [CrossRef]

52. Bradley, E.W.; Drissi, M.H. WNT5A regulates chondrocyte differentiation through differential use of the CaN/NFAT and IKK/NF-kappaB pathways. Mol. Endocrinol. 2010, 24, 1581-1593. [CrossRef]

53. Ikeda, T.; Kamekura, S.; Mabuchi, A.; Kou, I.; Seki, S.; Takato, T.; Nakamura, K.; Kawaguchi, H.; Ikegawa, S.; Chung, U.I. The combination of SOX5, SOX6, and SOX9 (the SOX trio) provides signals sufficient for induction of permanent cartilage. Arthritis Rheum. 2004, 50, 3561-3573. [CrossRef]

54. Kozhemyakina, E.; Lassar, A.B.; Zelzer, E. A pathway to bone: Signaling molecules and transcription factors involved in chondrocyte development and maturation. Development 2015, 142, 817-831. [CrossRef]

55. Topol, L.; Chen, W.; Song, H.; Day, T.F.; Yang, Y. Sox9 inhibits Wnt signaling by promoting beta-catenin phosphorylation in the nucleus. J. Biol. Chem. 2009, 284, 3323-3333. [CrossRef]

56. Akiyama, H.; Chaboissier, M.C.; Martin, J.F.; Schedl, A.; de Crombrugghe, B. The transcription factor Sox 9 has essential roles in successive steps of the chondrocyte differentiation pathway and is required for expression of Sox5 and Sox6. Genes Dev. 2002, 16, 2813-2828. [CrossRef]

57. Liu, C.F.; Lefebvre, V. The transcription factors SOX9 and SOX5/SOX6 cooperate genome-wide through super-enhancers to drive chondrogenesis. Nucleic Acids Res. 2015, 43, 8183-8203. [CrossRef]

58. Gaur, T.; Lengner, C.J.; Hovhannisyan, H.; Bhat, R.A.; Bodine, P.V.; Komm, B.S.; Javed, A.; van Wijnen, A.J.; Stein, J.L.; Stein, G.S.; et al. Canonical WNT signaling promotes osteogenesis by directly stimulating Runx2 gene expression. J. Biol. Chem. 2005, 280, 33132-33140. [CrossRef]

59. Liu, T.M.; Lee, E.H. Transcriptional regulatory cascades in Runx2-dependent bone development. Tissue Eng. Part B Rev. 2013, 19, 254-263. [CrossRef]

60. Roetzer, K.M.; Uyanik, G.; Brehm, A.; Zwerina, J.; Zandieh, S.; Czech, T.; Roschger, P.; Misof, B.M.; Klaushofer, K. Novel familial mutation of LRP5 causing high bone mass: Genetic analysis, clinical presentation, and characterization of bone matrix mineralization. Bone 2018, 107, 154-160. [CrossRef]

61. Mani, A.; Radhakrishnan, J.; Wang, H.; Mani, A.; Mani, M.A.; Nelson-Williams, C.; Carew, K.S.; Mane, S.; Najmabadi, H.; Wu, D.; et al. LRP6 mutation in a family with early coronary disease and metabolic risk factors. Science 2007, 315, 1278-1282. [CrossRef]

62. Malgor, R.; Bhatt, P.M.; Connolly, B.A.; Jacoby, D.L.; Feldmann, K.J.; Silver, M.J.; Nakazawa, M.; McCall, K.D.; Goetz, D.J. Wnt5a, TLR2 and TLR4 are elevated in advanced human atherosclerotic lesions. Inflamm. Res. 2014, 63, 277-285. [CrossRef] 
63. Bhatt, P.M.; Lewis, C.J.; House, D.L.; Keller, C.M.; Kohn, L.D.; Silver, M.J.; McCall, K.D.; Goetz, D.J.; Malgor, R. Increased Wnt5a mRNA Expression in Advanced Atherosclerotic Lesions, and Oxidized LDL Treated Human Monocyte-Derived Macrophages. Open Circ. Vasc. J. 2012, 5, 1-7. [CrossRef]

64. Woldt, E.; Terrand, J.; Mlih, M.; Matz, R.L.; Bruban, V.; Coudane, F.; Foppolo, S.; El Asmar, Z.; Chollet, M.E.; Ninio, E.; et al. The nuclear hormone receptor PPARgamma counteracts vascular calcification by inhibiting Wnt5a signalling in vascular smooth muscle cells. Nat. Commun. 2012, 3, 1077. [CrossRef]

65. Liu, J.; Zhang, L.; Zhou, Y.; Zhu, D.; Wang, Q.; Hao, L. Aberrant activation of Wnt pathways in arteries associates with vascular calcification in chronic kidney disease. Int. Urol. Nephrol. 2016, 48, 1313-1319. [CrossRef]

66. Akoumianakis, I.; Sanna, F.; Margaritis, M.; Badi, I.; Akawi, N.; Herdman, L.; Coutinho, P.; Fagan, H.; Antonopoulos, A.S.; Oikonomou, E.K.; et al. Adipose tissue-derived WNT5A regulates vascular redox signaling in obesity via USP17/RAC1-mediated activation of NADPH oxidases. Sci. Transl. Med. 2019, 11. [CrossRef]

67. Freise, C.; Kretzschmar, N.; Querfeld, U. Wnt signaling contributes to vascular calcification by induction of matrix metalloproteinases. BMC Cardiovasc. Disord. 2016, 16, 185. [CrossRef]

68. Pereira, C.; Schaer, D.J.; Bachli, E.B.; Kurrer, M.O.; Schoedon, G. Wnt5A/CaMKII signaling contributes to the inflammatory response of macrophages and is a target for the antiinflammatory action of activated protein C and interleukin-10. Arterioscler. Thromb. Vasc. Biol. 2008, 28, 504-510. [CrossRef]

69. Guan, S.; Wang, Z.; Xin, F.; Xin, H. Wnt5a is associated with the differentiation of bone marrow mesenchymal stem cells in vascular calcification by connecting with different receptors. Mol. Med. Rep. 2014, 10, 1985-1991. [CrossRef]

70. Zhu, M.; Fang, X.; Zhou, S.; Li, W.; Guan, S. Indirect coculture of vascular smooth muscle cells with bone marrow mesenchymal stem cells inhibits vascular calcification and downregulates the Wnt signaling pathways. Mol. Med. Rep. 2016, 13, 5141-5148. [CrossRef]

71. Liao, R.; Wang, L.; Li, J.; Sun, S.; Xiong, Y.; Li, Y.; Han, M.; Jiang, H.; Anil, M.; Su, B. Vascular calcification is associated with Wnt-signaling pathway and blood pressure variability in chronic kidney disease rats. Nephrology 2020, 25, 264-272. [CrossRef]

72. Cai, T.; Sun, D.; Duan, Y.; Wen, P.; Dai, C.; Yang, J.; He, W. WNT/beta-catenin signaling promotes VSMCs to osteogenic transdifferentiation and calcification through directly modulating Runx2 gene expression. Exp. Cell Res. 2016, 345, 206-217. [CrossRef]

73. Tian, B.Y.; Yao, L.; Sheng, Z.T.; Wan, P.Z.; Qiu, X.B.; Wang, J.; Xu, T.H. Specific knockdown of WNT8b expression protects against phosphate-induced calcification in vascular smooth muscle cells by inhibiting the Wnt-beta-catenin signaling pathway. J. Cell Physiol. 2019, 234, 3469-3477. [CrossRef]

74. Chen, Y.X.; Huang, C.; Duan, Z.B.; Xu, C.Y.; Chen, Y. Klotho/FGF23 axis mediates high phosphate-induced vascular calcification in vascular smooth muscle cells via Wnt7b/beta-catenin pathway. Kaohsiung J. Med. Sci. 2019, 35, 393-400. [CrossRef]

75. Lin, M.E.; Chen, T.; Leaf, E.M.; Speer, M.Y.; Giachelli, C.M. Runx2 Expression in Smooth Muscle Cells Is Required for Arterial Medial Calcification in Mice. Am. J. Pathol. 2015, 185, 1958-1969. [CrossRef]

76. Baetta, R.; Banfi, C. Dkk (Dickkopf) Proteins. Arterioscler. Thromb. Vasc. Biol. 2019, 39, 1330-1342. [CrossRef]

77. Claudel, M.; Jouzeau, J.Y.; Cailotto, F. Secreted Frizzled-related proteins (sFRPs) in osteo-articular diseases: Much more than simple antagonists of Wnt signaling? FEBS J. 2019, 286, 4832-4851. [CrossRef]

78. Reinhold, S.; Blankesteijn, W.M. Wnt/beta-Catenin Inhibitor Dickkopf 1. Arterioscler. Thromb. Vasc. Biol. 2019, 39, 121-123. [CrossRef]

79. Ueland, T.; Otterdal, K.; Lekva, T.; Halvorsen, B.; Gabrielsen, A.; Sandberg, W.J.; Paulsson-Berne, G.; Pedersen, T.M.; Folkersen, L.; Gullestad, L.; et al. Dickkopf-1 enhances inflammatory interaction between platelets and endothelial cells and shows increased expression in atherosclerosis. Arterioscler. Thromb. Vasc. Biol. 2009, 29, 1228-1234. [CrossRef]

80. Ueland, T.; Akerblom, A.; Ghukasyan, T.; Michelsen, A.E.; Becker, R.C.; Bertilsson, M.; Himmelmann, A.; James, S.K.; Siegbahn, A.; Storey, R.F.; et al. Admission Levels of DKK1 (Dickkopf-1) Are Associated With Future Cardiovascular Death in Patients With Acute Coronary Syndromes. Arterioscler. Thromb. Vasc. Biol. 2019, 39, 294-302. [CrossRef] 
81. Klingenschmid, G.; Tschiderer, L.; Himmler, G.; Rungger, G.; Brugger, S.; Santer, P.; Willeit, J.; Kiechl, S.; Willeit, P. Associations of Serum Dickkopf-1 and Sclerostin With Cardiovascular Events: Results From the Prospective Bruneck Study. J. Am. Heart Assoc. 2020, 9, e014816. [CrossRef]

82. Zhu, Z.; Guo, D.; Zhong, C.; Wang, A.; Xie, X.; Xu, T.; Chen, C.S.; Peng, Y.; Peng, H.; Li, Q.; et al. Serum Dkk-1 (Dickkopf-1) Is a Potential Biomarker in the Prediction of Clinical Outcomes Among Patients With Acute Ischemic Stroke. Arterioscler. Thromb. Vasc. Biol. 2019, 39, 285-293. [CrossRef]

83. Di, M.; Wang, L.; Li, M.; Zhang, Y.; Liu, X.; Zeng, R.; Wang, H.; Chen, Y.; Chen, W.; Zhang, Y.; et al. Dickkopf1 destabilizes atherosclerotic plaques and promotes plaque formation by inducing apoptosis of endothelial cells through activation of ER stress. Cell Death Dis. 2017, 8, e2917. [CrossRef] [PubMed]

84. Li, M.; Liu, X.; Zhang, Y.; Di, M.; Wang, H.; Wang, L.; Chen, Y.; Liu, X.; Cao, X.; Zeng, R.; et al. Upregulation of Dickkopf1 by oscillatory shear stress accelerates atherogenesis. J. Mol. Med. 2016, 94, 431-441. [CrossRef] [PubMed]

85. Evrard, S.M.; Lecce, L.; Michelis, K.C.; Nomura-Kitabayashi, A.; Pandey, G.; Purushothaman, K.R.; d'Escamard, V.; Li, J.R.; Hadri, L.; Fujitani, K.; et al. Endothelial to mesenchymal transition is common in atherosclerotic lesions and is associated with plaque instability. Nat. Commun. 2016, 7, 11853. [CrossRef] [PubMed]

86. Cheng, S.L.; Shao, J.S.; Behrmann, A.; Krchma, K.; Towler, D.A. Dkk1 and MSX2-Wnt7b signaling reciprocally regulate the endothelial-mesenchymal transition in aortic endothelial cells. Arterioscler. Thromb. Vasc. Biol. 2013, 33, 1679-1689. [CrossRef]

87. Szulc, P.; Schoppet, M.; Rachner, T.D.; Chapurlat, R.; Hofbauer, L.C. Severe abdominal aortic calcification in older men is negatively associated with DKK1 serum levels: The STRAMBO study. J. Clin. Endocrinol. Metab. 2014, 99, 617-624. [CrossRef]

88. Register, T.C.; Hruska, K.A.; Divers, J.; Bowden, D.W.; Palmer, N.D.; Carr, J.J.; Wagenknecht, L.E.; Hightower, R.C.; Xu, J.; Smith, S.C.; et al. Plasma Dickkopf1 (DKK1) concentrations negatively associate with atherosclerotic calcified plaque in African-Americans with type 2 diabetes. J. Clin. Endocrinol. Metab. 2013, 98, E60-E65. [CrossRef]

89. Sun, S.; Yu, M.; Fan, Z.; Yeh, I.T.; Feng, H.; Liu, H.; Han, D. DLX3 regulates osteogenic differentiation of bone marrow mesenchymal stem cells via Wnt/beta-catenin pathway mediated histone methylation of DKK4. Biochem. Biophys. Res. Commun. 2019, 516, 171-176. [CrossRef]

90. Devotta, A.; Hong, C.S.; Saint-Jeannet, J.P. Dkk2 promotes neural crest specification by activating Wnt/beta-catenin signaling in a GSK3beta independent manner. eLife 2018, 7. [CrossRef]

91. Li, X.; Liu, P.; Liu, W.; Maye, P.; Zhang, J.; Zhang, Y.; Hurley, M.; Guo, C.; Boskey, A.; Sun, L.; et al. Dkk2 has a role in terminal osteoblast differentiation and mineralized matrix formation. Nat. Genet. 2005, 37, 945-952. [CrossRef]

92. Wang, C.; Qiao, X.; Zhang, Z.; Li, C. MiR-128 promotes osteogenic differentiation of bone marrow mesenchymal stem cells in rat by targeting DKK2. Biosci. Rep. 2020, 40. [CrossRef] [PubMed]

93. Nakamura, R.E.; Hackam, A.S. Analysis of Dickkopf3 interactions with Wnt signaling receptors. Growth Factors 2010, 28, 232-242. [CrossRef] [PubMed]

94. Karamariti, E.; Zhai, C.; Yu, B.; Qiao, L.; Wang, Z.; Potter, C.M.F.; Wong, M.M.; Simpson, R.M.L.; Zhang, Z.; Wang, X.; et al. DKK3 (Dickkopf 3) Alters Atherosclerotic Plaque Phenotype Involving Vascular Progenitor and Fibroblast Differentiation Into Smooth Muscle Cells. Arterioscler. Thromb. Vasc. Biol. 2018, 38, 425-437. [CrossRef] [PubMed]

95. Oh, Y.J.; Kim, H.; Kim, A.J.; Ro, H.; Chang, J.H.; Lee, H.H.; Chung, W.; Jun, H.S.; Jung, J.Y. Reduction of Secreted Frizzled-Related Protein 5 Drives Vascular Calcification through Wnt3a-Mediated Rho/ROCK/JNK Signaling in Chronic Kidney Disease. Int. J. Mol. Sci. 2020, 21, 3539. [CrossRef]

96. Gaur, T.; Rich, L.; Lengner, C.J.; Hussain, S.; Trevant, B.; Ayers, D.; Stein, J.L.; Bodine, P.V.; Komm, B.S.; Stein, G.S.; et al. Secreted frizzled related protein 1 regulates Wnt signaling for BMP2 induced chondrocyte differentiation. J. Cell Physiol. 2006, 208, 87-96. [CrossRef] [PubMed]

97. Xavier, C.P.; Melikova, M.; Chuman, Y.; Uren, A.; Baljinnyam, B.; Rubin, J.S. Secreted Frizzled-related protein potentiation versus inhibition of Wnt3a/beta-catenin signaling. Cell Signal. 2014, 26, 94-101. [CrossRef] [PubMed] 
98. Hu, Z.; Deng, H.; Qu, H. Plasma SFRP5 levels are decreased in Chinese subjects with obesity and type 2 diabetes and negatively correlated with parameters of insulin resistance. Diabetes Res. Clin. Pr. 2013, 99, 391-395. [CrossRef]

99. Miyoshi, T.; Doi, M.; Usui, S.; Iwamoto, M.; Kajiya, M.; Takeda, K.; Nosaka, K.; Nakayama, R.; Okawa, K.; Takagi, W.; et al. Low serum level of secreted frizzled-related protein 5, an anti-inflammatory adipokine, is associated with coronary artery disease. Atherosclerosis 2014, 233, 454-459. [CrossRef]

100. Wang, D.; Zhang, Y.; Shen, C. Research update on the association between SFRP5, an anti-inflammatory adipokine, with obesity, type 2 diabetes mellitus and coronary heart disease. J. Cell Mol. Med. 2020, 24, 2730-2735. [CrossRef]

101. Deng, D.; Diao, Z.; Han, X.; Liu, W. Secreted Frizzled-Related Protein 5 Attenuates High Phosphate-Induced Calcification in Vascular Smooth Muscle Cells by Inhibiting the Wnt/ss-Catenin Pathway. Calcif. Tissue Int. 2016, 99, 66-75. [CrossRef]

102. Lefterova, M.I.; Haakonsson, A.K.; Lazar, M.A.; Mandrup, S. PPARgamma and the global map of adipogenesis and beyond. Trends Endocrinol. Metab. 2014, 25, 293-302. [CrossRef] [PubMed]

103. Ricote, M.; Glass, C.K. PPARs and molecular mechanisms of transrepression. Biochim. Biophys. Acta 2007, 1771, 926-935. [CrossRef] [PubMed]

104. Beyer, A.M.; Baumbach, G.L.; Halabi, C.M.; Modrick, M.L.; Lynch, C.M.; Gerhold, T.D.; Ghoneim, S.M.; de Lange, W.J.; Keen, H.L.; Tsai, Y.S.; et al. Interference with PPARgamma signaling causes cerebral vascular dysfunction, hypertrophy, and remodeling. Hypertension 2008, 51, 867-871. [CrossRef] [PubMed]

105. Halabi, C.M.; Beyer, A.M.; de Lange, W.J.; Keen, H.L.; Baumbach, G.L.; Faraci, F.M.; Sigmund, C.D. Interference with PPAR gamma function in smooth muscle causes vascular dysfunction and hypertension. Cell Metab. 2008, 7, 215-226. [CrossRef]

106. Giaginis, C.; Klonaris, C.; Katsargyris, A.; Kouraklis, G.; Spiliopoulou, C.; Theocharis, S. Correlation of Peroxisome Proliferator-Activated Receptor-gamma (PPAR-gamma) and Retinoid X Receptor-alpha (RXR-alpha) expression with clinical risk factors in patients with advanced carotid atherosclerosis. Med. Sci. Monit. 2011, 17, CR381-CR391. [CrossRef]

107. Vucic, E.; Dickson, S.D.; Calcagno, C.; Rudd, J.H.; Moshier, E.; Hayashi, K.; Mounessa, J.S.; Roytman, M.; Moon, M.J.; Lin, J.; et al. Pioglitazone modulates vascular inflammation in atherosclerotic rabbits noninvasive assessment with FDG-PET-CT and dynamic contrast-enhanced MR imaging. JACC Cardiovasc. Imaging 2011, 4, 1100-1109. [CrossRef]

108. Christoph, M.; Herold, J.; Berg-Holldack, A.; Rauwolf, T.; Ziemssen, T.; Schmeisser, A.; Weinert, S.; Ebner, B.; Said, S.; Strasser, R.H.; et al. Effects of the PPARgamma agonist pioglitazone on coronary atherosclerotic plaque composition and plaque progression in non-diabetic patients: A double-center, randomized controlled VH-IVUS pilot-trial. Heart Vessel. 2015, 30, 286-295. [CrossRef]

109. Ogasawara, D.; Shite, J.; Shinke, T.; Watanabe, S.; Otake, H.; Tanino, Y.; Sawada, T.; Kawamori, H.; Kato, H.; Miyoshi, N.; et al. Pioglitazone reduces the necrotic-core component in coronary plaque in association with enhanced plasma adiponectin in patients with type 2 diabetes mellitus. Circ. J. 2009, 73, 343-351. [CrossRef]

110. Lim, S.; Lee, K.S.; Lee, J.E.; Park, H.S.; Kim, K.M.; Moon, J.H.; Choi, S.H.; Park, K.S.; Kim, Y.B.; Jang, H.C. Effect of a new PPAR-gamma agonist, lobeglitazone, on neointimal formation after balloon injury in rats and the development of atherosclerosis. Atherosclerosis 2015, 243, 107-119. [CrossRef]

111. Liu, L.; Liu, Y.; Zhang, Y.; Bi, X.; Nie, L.; Liu, C.; Xiong, J.; He, T.; Xu, X.; Yu, Y.; et al. High phosphate-induced downregulation of PPARgamma contributes to CKD-associated vascular calcification. J. Mol. Cell. Cardiol. 2018, 114, 264-275. [CrossRef]

112. Zhou, Y.B.; Zhang, J.; Peng, D.Q.; Chang, J.R.; Cai, Y.; Yu, Y.R.; Jia, M.Z.; Wu, W.; Guan, Y.F.; Tang, C.S.; et al. Peroxisome proliferator-activated receptor gamma ligands retard cultured vascular smooth muscle cells calcification induced by high glucose. Cell Biochem. Biophys. 2013, 66, 421-429. [CrossRef] [PubMed]

113. Liu, C.; Feng, X.; Li, Q.; Wang, Y.; Li, Q.; Hua, M. Adiponectin, TNF-alpha and inflammatory cytokines and risk of type 2 diabetes: A systematic review and meta-analysis. Cytokine 2016, 86, 100-109. [CrossRef] [PubMed]

114. Cainzos-Achirica, M.; Enjuanes, C.; Greenland, P.; McEvoy, J.W.; Cushman, M.; Dardari, Z.; Nasir, K.; Budoff, M.J.; Al-Mallah, M.H.; Yeboah, J.; et al. The prognostic value of interleukin 6 in multiple chronic diseases and all-cause death: The Multi-Ethnic Study of Atherosclerosis (MESA). Atherosclerosis 2018, 278, 217-225. [CrossRef] [PubMed] 
115. Kaptoge, S.; Seshasai, S.R.; Gao, P.; Freitag, D.F.; Butterworth, A.S.; Borglykke, A.; Di Angelantonio, E.; Gudnason, V.; Rumley, A.; Lowe, G.D.; et al. Inflammatory cytokines and risk of coronary heart disease: New prospective study and updated meta-analysis. Eur. Heart J. 2014, 35, 578-589. [CrossRef] [PubMed]

116. Kaminska, J.; Stopinski, M.; Mucha, K.; Jedrzejczak, A.; Golebiowski, M.; Niewczas, M.A.; Paczek, L.; Foroncewicz, B. IL 6 but not TNF is linked to coronary artery calcification in patients with chronic kidney disease. Cytokine 2019, 120, 9-14. [CrossRef] [PubMed]

117. Zickler, D.; Luecht, C.; Willy, K.; Chen, L.; Witowski, J.; Girndt, M.; Fiedler, R.; Storr, M.; Kamhieh-Milz, J.; Schoon, J.; et al. Tumour necrosis factor-alpha in uraemic serum promotes osteoblastic transition and calcification of vascular smooth muscle cells via extracellular signal-regulated kinases and activator protein 1/c-FOS-mediated induction of interleukin 6 expression. Nephrol. Dial. Transpl. 2018, 33, 574-585. [CrossRef] [PubMed]

118. Lopez-Mejias, R.; Gonzalez-Gay, M.A. IL-6: Linking chronic inflammation and vascular calcification. Nat. Rev. Rheumatol. 2019, 15, 457-459. [CrossRef]

119. Al-Aly, Z. Arterial calcification: A tumor necrosis factor-alpha mediated vascular Wnt-opathy. Transl. Res. 2008, 151, 233-239. [CrossRef]

120. Bessueille, L.; Fakhry, M.; Hamade, E.; Badran, B.; Magne, D. Glucose stimulates chondrocyte differentiation of vascular smooth muscle cells and calcification: A possible role for IL-1beta. FEBS Lett. 2015, 589, 2797-2804. [CrossRef]

121. Heming, M.; Gran, S.; Jauch, S.L.; Fischer-Riepe, L.; Russo, A.; Klotz, L.; Hermann, S.; Schafers, M.; Roth, J.; Barczyk-Kahlert, K. Peroxisome Proliferator-Activated Receptor-gamma Modulates the Response of Macrophages to Lipopolysaccharide and Glucocorticoids. Front. Immunol. 2018, 9, 893. [CrossRef]

122. Bouhlel, M.A.; Derudas, B.; Rigamonti, E.; Dievart, R.; Brozek, J.; Haulon, S.; Zawadzki, C.; Jude, B.; Torpier, G.; Marx, N.; et al. PPARgamma activation primes human monocytes into alternative M2 macrophages with anti-inflammatory properties. Cell Metab. 2007, 6, 137-143. [CrossRef]

123. Daniel, B.; Nagy, G.; Czimmerer, Z.; Horvath, A.; Hammers, D.W.; Cuaranta-Monroy, I.; Poliska, S.; Tzerpos, P.; Kolostyak, Z.; Hays, T.T.; et al. The Nuclear Receptor PPARgamma Controls Progressive Macrophage Polarization as a Ligand-Insensitive Epigenomic Ratchet of Transcriptional Memory. Immunity 2018, 49, 615-626.e6. [CrossRef]

124. de Gaetano, M.; Crean, D.; Barry, M.; Belton, O. M1- and M2-Type Macrophage Responses Are Predictive of Adverse Outcomes in Human Atherosclerosis. Front. Immunol. 2016, 7, 275. [CrossRef] [PubMed]

125. Zelova, H.; Hosek, J. TNF-alpha signalling and inflammation: Interactions between old acquaintances. Inflamm. Res. 2013, 62, 641-651. [CrossRef] [PubMed]

126. Li, J.; Shen, X. Effect of rosiglitazone on inflammatory cytokines and oxidative stress after intensive insulin therapy in patients with newly diagnosed type 2 diabetes. Diabetol. Metab. Syndr. 2019, 11, 35. [CrossRef] [PubMed]

127. Jiang, C.; Ting, A.T.; Seed, B. PPAR-gamma agonists inhibit production of monocyte inflammatory cytokines. Nature 1998, 391, 82-86. [CrossRef] [PubMed]

128. Kuro, O.M. The Klotho proteins in health and disease. Nat. Rev. Nephrol. 2019, 15, 27-44. [CrossRef]

129. Moreno, J.A.; Izquierdo, M.C.; Sanchez-Nino, M.D.; Suarez-Alvarez, B.; Lopez-Larrea, C.; Jakubowski, A.; Blanco, J.; Ramirez, R.; Selgas, R.; Ruiz-Ortega, M.; et al. The inflammatory cytokines TWEAK and TNFalpha reduce renal klotho expression through NFkappaB. J. Am. Soc. Nephrol. 2011, 22, 1315-1325. [CrossRef]

130. Lim, K.; Lu, T.S.; Molostvov, G.; Lee, C.; Lam, F.T.; Zehnder, D.; Hsiao, L.L. Vascular Klotho deficiency potentiates the development of human artery calcification and mediates resistance to fibroblast growth factor 23. Circulation 2012, 125, 2243-2255. [CrossRef]

131. Pavik, I.; Jaeger, P.; Ebner, L.; Wagner, C.A.; Petzold, K.; Spichtig, D.; Poster, D.; Wuthrich, R.P.; Russmann, S.; Serra, A.L. Secreted Klotho and FGF23 in chronic kidney disease Stage 1 to 5: A sequence suggested from a cross-sectional study. Nephrol. Dial. Transpl. 2013, 28, 352-359. [CrossRef]

132. Hu, M.C.; Shi, M.; Zhang, J.; Quinones, H.; Griffith, C.; Kuro-o, M.; Moe, O.W. Klotho deficiency causes vascular calcification in chronic kidney disease. J. Am. Soc. Nephrol. 2011, 22, 124-136. [CrossRef] [PubMed]

133. Cheng, L.; Zhang, L.; Yang, J.; Hao, L. Activation of peroxisome proliferator-activated receptor gamma inhibits vascular calcification by upregulating Klotho. Exp. Med. 2017, 13, 467-474. [CrossRef] [PubMed] 
134. Glosse, P.; Fajol, A.; Hirche, F.; Feger, M.; Voelkl, J.; Lang, F.; Stangl, G.I.; Foller, M. A high-fat diet stimulates fibroblast growth factor 23 formation in mice through TNFalpha upregulation. Nutr. Diabetes 2018, 8, 36. [CrossRef] [PubMed]

135. Rios, R.; Pineda, C.; Lopez, I.; Munoz-Castaneda, J.; Rodriguez, M.; Aguilera-Tejero, E.; Raya, A.I. Phosphorus restriction does not prevent the increase in fibroblast growth factor 23 elicited by high fat diet. PLoS ONE 2018, 13, e0198481. [CrossRef] [PubMed]

136. Tan, L.; Wang, Z.; Li, Y. Rabbit models provide insights into bone formation related biological process in atherosclerotic vascular calcification. Biochem. Biophys. Res. Commun. 2018, 496, 1369-1375. [CrossRef] [PubMed]

137. Zhang, H.; Li, Y.; Fan, Y.; Wu, J.; Zhao, B.; Guan, Y.; Chien, S.; Wang, N. Klotho is a target gene of PPAR-gamma. Kidney Int. 2008, 74, 732-739. [CrossRef] [PubMed]

138. Lin, W.; Zhang, Q.; Liu, L.; Yin, S.; Liu, Z.; Cao, W. Klotho restoration via acetylation of Peroxisome Proliferation-Activated Receptor gamma reduces the progression of chronic kidney disease. Kidney Int. 2017, 92, 669-679. [CrossRef]

139. Usuda, D.; Kanda, T. Peroxisome proliferator-activated receptors for hypertension. World J. Cardiol. 2014, 6, 744-754. [CrossRef]

140. Maquigussa, E.; Paterno, J.C.; de Oliveira Pokorny, G.H.; da Silva Perez, M.; Varela, V.A.; da Silva Novaes, A.; Schor, N.; Boim, M.A. Klotho and PPAR Gamma Activation Mediate the Renoprotective Effect of Losartan in the 5/6 Nephrectomy Model. Front. Physiol. 2018, 9, 1033. [CrossRef]

141. Kukida, M.; Mogi, M.; Kan-No, H.; Tsukuda, K.; Bai, H.Y.; Shan, B.S.; Yamauchi, T.; Higaki, A.; Min, L.J.; Iwanami, J.; et al. AT2 receptor stimulation inhibits phosphate-induced vascular calcification. Kidney Int. 2019, 95, 138-148. [CrossRef]

142. Kukida, M.; Mogi, M.; Ohshima, K.; Nakaoka, H.; Iwanami, J.; Kanno, H.; Tsukuda, K.; Chisaka, T.; Min, L.J.; Wang, X.L.; et al. Angiotensin II Type 2 Receptor Inhibits Vascular Intimal Proliferation With Activation of PPARgamma. Am. J. Hypertens. 2016, 29, 727-736. [CrossRef] [PubMed]

143. Cawthorn, W.P.; Bree, A.J.; Yao, Y.; Du, B.; Hemati, N.; Martinez-Santibanez, G.; MacDougald, O.A. Wnt6, Wnt10a and Wnt10b inhibit adipogenesis and stimulate osteoblastogenesis through a beta-catenin-dependent mechanism. Bone 2012, 50, 477-489. [CrossRef] [PubMed]

144. Fu, M.; Rao, M.; Bouras, T.; Wang, C.; Wu, K.; Zhang, X.; Li, Z.; Yao, T.P.; Pestell, R.G. Cyclin D1 inhibits peroxisome proliferator-activated receptor gamma-mediated adipogenesis through histone deacetylase recruitment. J. Biol. Chem. 2005, 280, 16934-16941. [CrossRef] [PubMed]

145. Shtutman, M.; Zhurinsky, J.; Simcha, I.; Albanese, C.; D'Amico, M.; Pestell, R.; Ben-Ze'ev, A. The cyclin D1 gene is a target of the beta-catenin/LEF-1 pathway. Proc. Natl. Acad. Sci. USA 1999, 96, 5522-5527. [CrossRef]

146. Wang, C.; Pattabiraman, N.; Zhou, J.N.; Fu, M.; Sakamaki, T.; Albanese, C.; Li, Z.; Wu, K.; Hulit, J.; Neumeister, P.; et al. Cyclin D1 repression of peroxisome proliferator-activated receptor gamma expression and transactivation. Mol. Cell. Biol. 2003, 23, 6159-6173. [CrossRef] [PubMed]

147. Vallee, A.; Vallee, J.N.; Lecarpentier, Y. Metabolic reprogramming in atherosclerosis: Opposed interplay between the canonical WNT/beta-catenin pathway and PPARgamma. J. Mol. Cell. Cardiol. 2019, 133, 36-46. [CrossRef]

148. Kawata, K.; Kubota, S.; Eguchi, T.; Moritani, N.H.; Shimo, T.; Kondo, S.; Nishida, T.; Minagi, S.; Takigawa, M. Role of the low-density lipoprotein receptor-related protein-1 in regulation of chondrocyte differentiation. J. Cell. Physiol. 2010, 222, 138-148. [CrossRef] [PubMed]

149. El Asmar, Z.; Terrand, J.; Jenty, M.; Host, L.; Mlih, M.; Zerr, A.; Justiniano, H.; Matz, R.L.; Boudier, C.; Scholler, E.; et al. Convergent Signaling Pathways Controlled by LRP1 (Receptor-related Protein 1) Cytoplasmic and Extracellular Domains Limit Cellular Cholesterol Accumulation. J. Biol. Chem. 2016, 291, 5116-5127. [CrossRef]

150. Borland, S.J.; Morris, T.G.; Borland, S.C.; Morgan, M.R.; Francis, S.E.; Merry, C.L.R.; Canfield, A.E. Regulation of vascular smooth muscle cell calcification by syndecan-4/FGF-2/PKCalpha signalling and cross-talk with TGFbeta. Cardiovasc. Res. 2017, 113, 1639-1652. [CrossRef]

151. Wan, M.; Li, C.; Zhen, G.; Jiao, K.; He, W.; Jia, X.; Wang, W.; Shi, C.; Xing, Q.; Chen, Y.F.; et al. Injury-activated transforming growth factor beta controls mobilization of mesenchymal stem cells for tissue remodeling. Stem Cells 2012, 30, 2498-2511. [CrossRef] 
152. Potere, N.; Del Buono, M.G.; Mauro, A.G.; Abbate, A.; Toldo, S. Low Density Lipoprotein Receptor-Related Protein-1 in Cardiac Inflammation and Infarct Healing. Front. Cardiovasc. Med. 2019, 6, 51. [CrossRef] [PubMed]

153. Simionescu, A.; Philips, K.; Vyavahare, N. Elastin-derived peptides and TGF-beta1 induce osteogenic responses in smooth muscle cells. Biochem. Biophys. Res. Commun. 2005, 334, 524-532. [CrossRef] [PubMed]

154. Zeng, J.; Hu, J.; Lian, Y.; Jiang, Y.; Chen, B. SFRP5 is a target gene transcriptionally regulated by PPARgamma in 3T3-L1 adipocytes. Gene 2018, 641, 190-195. [CrossRef] [PubMed]

155. Catalan, V.; Gomez-Ambrosi, J.; Rodriguez, A.; Perez-Hernandez, A.I.; Gurbindo, J.; Ramirez, B.; Mendez-Gimenez, L.; Rotellar, F.; Valenti, V.; Moncada, R.; et al. Activation of noncanonical Wnt signaling through WNT5A in visceral adipose tissue of obese subjects is related to inflammation. J. Clin. Endocrinol. Metab. 2014, 99, E1407-E1417. [CrossRef]

156. Zhao, C.; Bu, X.; Wang, W.; Ma, T.; Ma, H. GEC-derived SFRP5 inhibits Wnt5a-induced macrophage chemotaxis and activation. PLoS ONE 2014, 9, e85058. [CrossRef]

157. Au, D.T.; Migliorini, M.; Strickland, D.K.; Muratoglu, S.C. Macrophage LRP1 Promotes Diet-Induced Hepatic Inflammation and Metabolic Dysfunction by Modulating Wnt Signaling. Mediat. Inflamm. 2018, 2018, 7902841. [CrossRef]

158. Cho, E.S.; Kim, M.K.; Son, Y.O.; Lee, K.S.; Park, S.M.; Lee, J.C. The effects of rosiglitazone on osteoblastic differentiation, osteoclast formation and bone resorption. Mol. Cells 2012, 33, 173-181. [CrossRef]

159. Benvenuti, S.; Cellai, I.; Luciani, P.; Deledda, C.; Baglioni, S.; Giuliani, C.; Saccardi, R.; Mazzanti, B.; Dal Pozzo, S.; Mannucci, E.; et al. Rosiglitazone stimulates adipogenesis and decreases osteoblastogenesis in human mesenchymal stem cells. J. Endocrinol. Investig. 2007, 30, RC26-RC30. [CrossRef]

160. Gao, M.; Chen, T.; Wu, L.; Zhao, X.; Mao, H.; Xing, C. Effect of pioglitazone on the calcification of rat vascular smooth muscle cells through the downregulation of the Wnt/betacatenin signaling pathway. Mol. Med. Rep. 2017, 16, 6208-6213. [CrossRef]

161. Mu, Q.; Fang, X.; Li, X.; Zhao, D.; Mo, F.; Jiang, G.; Yu, N.; Zhang, Y.; Guo, Y.; Fu, M.; et al. Ginsenoside $\mathrm{Rb} 1$ promotes browning through regulation of PPARgamma in 3T3-L1 adipocytes. Biochem. Biophys. Res. Commun. 2015, 466, 530-535. [CrossRef]

162. Chan, L.S.; Yue, P.Y.; Kok, T.W.; Keung, M.H.; Mak, N.K.; Wong, R.N. Ginsenoside-Rb1 promotes adipogenesis through regulation of PPARgamma and microRNA-27b. Horm. Metab. Res. 2012, 44, 819-824. [CrossRef] [PubMed]

163. Zhou, P.; Zhang, X.; Guo, M.; Guo, R.; Wang, L.; Zhang, Z.; Lin, Z.; Dong, M.; Dai, H.; Ji, X.; et al. Ginsenoside $\mathrm{Rb} 1$ ameliorates CKD-associated vascular calcification by inhibiting the Wnt/beta-catenin pathway. J. Cell. Mol. Med. 2019, 23, 7088-7098. [CrossRef] [PubMed]

164. Kanai, S.; Uto, K.; Honda, K.; Hagiwara, N.; Oda, H. Eicosapentaenoic acid reduces warfarin-induced arterial calcification in rats. Atherosclerosis 2011, 215, 43-51. [CrossRef] [PubMed]

165. Saito, Y.; Nakamura, K.; Miura, D.; Yunoki, K.; Miyoshi, T.; Yoshida, M.; Kawakita, N.; Kimura, T.; Kondo, M.; Sarashina, T.; et al. Suppression of Wnt Signaling and Osteogenic Changes in Vascular Smooth Muscle Cells by Eicosapentaenoic Acid. Nutrients 2017, 9, 858. [CrossRef]

166. Marion-Letellier, R.; Savoye, G.; Ghosh, S. Fatty acids, eicosanoids and PPAR gamma. Eur. J. Pharm. 2016, 785, 44-49. [CrossRef]

167. Nakamura, K.; Miura, D.; Saito, Y.; Yunoki, K.; Koyama, Y.; Satoh, M.; Kondo, M.; Osawa, K.; Hatipoglu, O.F.; Miyoshi, T.; et al. Eicosapentaenoic acid prevents arterial calcification in klotho mutant mice. PLoS ONE 2017, 12, e0181009. [CrossRef]

168. Liu, H.; Fergusson, M.M.; Castilho, R.M.; Liu, J.; Cao, L.; Chen, J.; Malide, D.; Rovira, I., II; Schimel, D.; Kuo, C.J.; et al. Augmented Wnt signaling in a mammalian model of accelerated aging. Science 2007, 317, 803-806. [CrossRef]

169. Zhou, L.; Li, Y.; Zhou, D.; Tan, R.J.; Liu, Y. Loss of Klotho contributes to kidney injury by derepression of Wnt/beta-catenin signaling. J. Am. Soc. Nephrol. 2013, 24, 771-785. [CrossRef]

170. Gustafson, B.; Eliasson, B.; Smith, U. Thiazolidinediones increase the wingless-type MMTV integration site family (WNT) inhibitor Dickkopf-1 in adipocytes: A link with osteogenesis. Diabetologia 2010, 53, 536-540. [CrossRef] 
171. Stechschulte, L.A.; Czernik, P.J.; Rotter, Z.C.; Tausif, F.N.; Corzo, C.A.; Marciano, D.P.; Asteian, A.; Zheng, J.; Bruning, J.B.; Kamenecka, T.M.; et al. PPARG Post-translational Modifications Regulate Bone Formation and Bone Resorption. EBioMedicine 2016, 10, 174-184. [CrossRef]

172. Tejeda-Munoz, N.; Robles-Flores, M. Glycogen synthase kinase 3 in Wnt signaling pathway and cancer. Iubmb. Life 2015, 67, 914-922. [CrossRef] [PubMed]

173. Sharma, C.; Pradeep, A.; Wong, L.; Rana, A.; Rana, B. Peroxisome proliferator-activated receptor gamma activation can regulate beta-catenin levels via a proteasome-mediated and adenomatous polyposis coli-independent pathway. J. Biol. Chem. 2004, 279, 35583-35594. [CrossRef] [PubMed]

174. Liu, J.; Farmer, S.R. Regulating the balance between peroxisome proliferator-activated receptor gamma and beta-catenin signaling during adipogenesis. A glycogen synthase kinase 3beta phosphorylation-defective mutant of beta-catenin inhibits expression of a subset of adipogenic genes. J. Biol. Chem. 2004, 279, 45020-45027. [CrossRef] [PubMed]

175. Liu, J.; Wang, H.; Zuo, Y.; Farmer, S.R. Functional interaction between peroxisome proliferator-activated receptor gamma and beta-catenin. Mol. Cell. Biol. 2006, 26, 5827-5837. [CrossRef] [PubMed]

176. Li, S.J.; Kao, Y.H.; Chung, C.C.; Cheng, W.L.; Chen, Y.J. HDAC I inhibitor regulates RUNX2 transactivation through canonical and non-canonical Wnt signaling in aortic valvular interstitial cells. Am. J. Transl. Res. 2019, 11, 744-754.

177. Gao, Z.; He, Q.; Peng, B.; Chiao, P.J.; Ye, J. Regulation of nuclear translocation of HDAC3 by IkappaBalpha is required for tumor necrosis factor inhibition of peroxisome proliferator-activated receptor gamma function. J. Biol. Chem. 2006, 281, 4540-4547. [CrossRef]

178. Kwon, D.H.; Ryu, J.; Kim, Y.K.; Kook, H. Roles of Histone Acetylation Modifiers and Other Epigenetic Regulators in Vascular Calcification. Int. J. Mol. Sci. 2020, 21, 3246. [CrossRef]

Publisher's Note: MDPI stays neutral with regard to jurisdictional claims in published maps and institutional affiliations. 